\title{
Too Fast, Too Frequent? High-Frequency Trading and Securities Class Actions
}

\author{
Tara E. Levens†
}

\section{INTRODUCTION}

An individual investor calls his broker and requests $\$ 100,000$ of a certain stock for his portfolio. The broker sees that shares of that stock are currently being offered at $\$ 10$ a share, and that there are 4,000 shares available on the New York Stock Exchange (NYSE), 3,000 on NASDAQ, and 3,000 on the BATS Global Exchange, for a total of 10,000 shares. ${ }^{1}$ Satisfied with his ability to fulfill his client's request, the broker hits "submit"only to find that these offerings have disappeared and that the cheapest offering price of the stock is now above $\$ 10$ a share, resulting in a purchase of fewer than the expected 10,000 shares for his client.

This rapid, blink-of-an-eye increase in price is but one side effect of high-frequency trading (HFT), the newest technology to affect the stock market. Because the broker in our story was located at different physical distances from the NYSE, NASDAQ, and BATS servers, the various pieces of his order reached each exchange at different times. Due to faster fiber-optic cables and closer proximity to the exchanges' servers, high-frequency traders saw the first portion of the broker's order on one exchange, registered that he was interested in purchasing that security, bought it themselves on the second exchange, and offered it back to the broker at a higher price when his request reached the second exchange-and so on, until his order was filled. As a result, after the broker completed the order, his client ended up with

$\dagger$ BA 2012, The University of Chicago; JD Candidate 2016, The University of Chicago Law School.

1 The BATS Global Exchange is currently one of the largest US equities-market operators. As of April 1, 2015, NYSE had a 22.20 percent market share, NASDAQ had 18.79 percent, and BATS had 22.61 percent. See U.S. Equities Market Volume Summary (BATS Global Markets), archived at http://perma.cc/C69K-2EFR. BATS operates four different exchanges: BATS BZX Exchange, BYX Exchange, EDGA Exchange, and EDGX Exchange. The latter two exchanges were formerly known as the Direct Edge Exchange and have been acquired by BATS. 
fewer than the anticipated 10,000 shares due to the increased share price-all because high-frequency traders saw the order coming.

HFT has been gaining traction in the marketplace since the late 2000 s and will likely continue to increase its share over time as investors seek access to higher speeds and faster trades. Along with the advantages of increased speed, however, come many negative effects for investors still utilizing slower, moreconventional electronic trading strategies. Such investors, stung by lost profits and increased prices, have begun to seek protection and relief through the federal securities laws-but how likely are their claims to succeed? And, in the event that HFT becomes a standard practice among investors, how should litigants in securities class actions react to this new technology?

This Comment addresses these questions in three parts. Part I lays out the existing legal framework behind securitiesfraud class actions and the fraud-on-the-market presumption of reliance that has proven so vital to these class actions. Part II provides an overview of technical HFT strategies and mechanisms, discusses HFT's impact on market efficiency, and then evaluates current legal challenges to HFT. Finally, Part III explores the various strategies available to plaintiffs seeking to recover against HFT firms and argues for both a hybrid misrepresentation/manipulation theory of liability as well as further exploration of an open-market manipulation theory of liability. In addition, Part III addresses the possibility that investors using HFT strategies may seek access to the courts as plaintiffs and argues that procedural hurdles will pose unique difficulties if such suits are brought as class actions.

\section{The Existing Framework of Securities-Fraud Class ACTIONS}

The advent of HFT presents complicated issues within the existing landscape of securities-fraud class actions. To fully understand these changes and determine the best ways of incorporating high-frequency traders into the legal arena, it is first necessary to examine how investors currently seek recourse for losses incurred on the market.

This Part proceeds in two stages. Part I.A provides an overview of securities-fraud class actions and the requirements for pleading a prima facie case of securities fraud. It focuses on the provisions relating to manipulation and distinguishes the 
various causes of action arising from $\S \S 9$ and $10(\mathrm{~b})$ of the Securities Exchange Act of $1934^{2}$ ("Exchange Act"). Part I.B then explains the difficulties in satisfying the procedural requirements of Federal Rule of Civil Procedure (FRCP) 23(b)(3) and introduces the accepted solution to this problem: the fraud-onthe-market presumption of reliance. Part I.B also explores the theoretical foundation of fraud on the market, the predicates required to invoke the presumption, and the methods by which defendants can rebut the presumption. After summarizing current litigation aimed specifically at the various requirements of the fraud-on-the-market presumption, Part I.B identifies changes that recent cases have made to courts' understandings of those predicates and analyzes the most recent Supreme Court case addressing the fraud-on-the-market presumption.

\section{A. Causes of Action under the Exchange Act}

Plaintiffs seeking recovery for losses incurred during trading can look to many federal statutory provisions. The provisions most relevant to HFT are those addressing market manipulation and deceptive conduct. This Section outlines the pleading requirements for claims of fraudulent misrepresentation under $\S 10(\mathrm{~b})$ and also addresses the less commonly utilized open market and $\S 9$ theories of manipulation.

1. Liability for fraudulent misrepresentations under $\S 10(\mathrm{~b})$ and Rule 10b-5.

Securities-fraud claims are most often brought under $\S 10(b)$ of the Exchange Act, which bars the use of "any manipulative or deceptive device" in contravention of any rules or regulations involving the national securities exchanges. ${ }^{3}$ Section $10(\mathrm{~b})$ has been referred to as a "catchall provision," as it "lumps together into a brief, all-encompassing rule the prohibitions on market manipulation and on material misrepresentations or omissions, categorizing them all as species of 'fraud' or 'deceit."' ${ }_{4}$ After the passage of the Exchange Act, the Securities and Exchange Commission (SEC) promulgated Rule 10b-5, which prohibits any act or omission resulting in fraud or deceit in connection with

2 Pub L No 73-291, 48 Stat 881, codified as amended at 15 USC $§ 78$ a et seq.

$3 \quad 15$ USC $\$ 78 \mathrm{j}(\mathrm{b})$.

4 Charles R. Korsmo, Mismatch: The Misuse of Market Efficiency in Market Manipulation Class Actions, 52 Wm \& Mary L Rev 1111, 1120-21 (2011). 
the purchase or sale of any security. ${ }^{5}$ While neither $\S 10(b)$ nor Rule 10b-5 expressly provides for a private right of action, courts have recognized such actions as implied by both the statute and the regulation. ${ }^{6}$ Civil actions and SEC enforcement actions brought under a Rule $10 \mathrm{~b}-5$ theory of liability typically allege material misrepresentations or omissions, often made in quarterly phone calls reporting earnings to investors or in other public pronouncements by issuers and their executives once a security is trading in the secondary markets. The Rule was enacted in part to combat such dishonest practices. ${ }^{7}$ To prevail in a Rule 10b-5 action, a private plaintiff must prove six elements: "(1) a material misrepresentation or omission by the defendant; (2) scienter; (3) a connection between the misrepresentation or omission and the purchase or sale of a security; (4) reliance upon the misrepresentation or omission; (5) economic loss; and (6) loss causation."8

\section{Market manipulation and open-market manipulation under $§ 10(b)$.}

In addition to allegations of fraudulent misrepresentation, plaintiffs may also bring market manipulation claims under $\S 10(b)$. Such claims have received "curiously little attention"

5 Rule $10 \mathrm{~b}-5$ provides, in relevant part, that it is unlawful for any person:
(a) To employ any device, scheme, or artifice to defraud,
(b) To make any untrue statement of a material fact or to omit to state a mate- rial fact necessary in order to make the statements made, in the light of the circumstances under which they were made, not misleading, or
(c) To engage in any act, practice, or course of business which operates or would operate as a fraud or deceit upon any person,
in connection with the purchase or sale of any security.

17 CFR § 240.10b-5.

6 See Superintendent of Insurance of New York v Bankers Life \& Casualty Co, 404 US 6,13 n 9 (1971).

7 See Securities Exchange Bill of 1934, HR Rep No 73-1383, 73d Cong, 2d Sess 11 (1934) ("To make effective the prohibitions against manipulation civil redress is given to those able to prove actual damages from any of the prohibited practices."); Federal Securities Exchange Act of 1934, S Rep No 73-792, 73d Cong, 2d Sess 7-8 (1934) (stating that the bill bans "the dissemination of false information and tipster sheets").

8 Amgen Inc $v$ Connecticut Retirement Plans and Trust Funds, $133 \mathrm{~S} \mathrm{Ct} 1184,1192$ (2013) (quotation marks omitted). This Comment focuses on Rule 10b-5 actions brought by private plaintiffs; note that SEC enforcement actions have different pleading standards. See, for example, Securities and Exchange Commission v Wolfson, 539 F3d 1249, 1256 (10th Cir 2008), quoting Geman v Securities and Exchange Commission, 334 F3d 1183, 1191 (10th Cir 2003) ("Unlike private litigants proceeding under $\S 10(\mathrm{~b})$, ' $[\mathrm{t}] \mathrm{he}$ SEC is not required to prove reliance or injury in enforcement actions."'). 
from plaintiffs, prosecutors, and courts. ${ }^{9}$ The elements of a prima facie case are slightly different from those of a misrepresentation claim and consist of the following: "(1) manipulative acts; (2) damage (3) caused by reliance on an assumption of an efficient market free of manipulation; (4) scienter; (5) in connection with the purchase or sale of securities; (6) furthered by the defendant's use of the mails or any facility of a national securities exchange." 10 As a result of the different pleading requirements, a plaintiff in the early stages of a market manipulation case "need not plead manipulation to the same degree of specificity as a plain misrepresentation claim."11

An alternative, more highly contested theory of liability under $\S 10(b)$ and Rule $10 b-5$, which takes market manipulation as its starting point, is that of open-market manipulation. The distinction between these two theories lies in how the alleged manipulator creates the price movement that causes his profit: traditional manipulation involves conduct that is "inherently or otherwise illegal, such as fictitious transactions, wash sales," or the dissemination of false reporting, ${ }^{12}$ whereas open-market manipulation consists of facially legitimate transactions that make the fraud harder to detect. ${ }^{13}$ Claims of open-market manipulation allege attempts to "increase the price of a security or com. modity by trading, and to sell at a profit before the price returns to its 'correct' level." 14 However, because these transactions are otherwise-unremarkable trades, courts have hesitated to condemn this behavior when the claims are based solely on manipulative intent, and they have varied in their treatment of this issue. For example, the Third Circuit has held that manipulative intent alone is an insufficient basis for liability and requires a further showing "that the alleged manipulator injected "inaccurate information' into the market or created a false impression

9 Barbara Black, The Strange Case of Fraud on the Market: A Label in Search of a Theory, 52 Albany L Rev 923, 950 (1988).

10 ATSI Communications, Inc v Shaar Fund, Ltd, 493 F3d 87, 101 (2d Cir 2007).

11 Id at 102. Claims of manipulation must describe the "nature, purpose, and effect of the fraudulent conduct and the roles of the defendants." Id. More general claims of misrepresentation, on the other hand, require identification of the precise statements relied on by the plaintiffs and greater factual detail. See Amgen, $133 \mathrm{~S} \mathrm{Ct}$ at 1192.

12 Maxwell K. Multer, Open-Market Manipulation under SEC Rule 10b-5 and Its Analogues: Inappropriate Distinctions, Judicial Disagreement and Case Study; Ferc's Anti-manipulation Rule, $39 \mathrm{Sec}$ Reg L J 97, 98 (2011).

13 See id at 101-02.

14 Id at 103. 
of market activity." 15 In contrast, the DC Circuit has instead relied on the legislative intent underlying the Exchange Act to find that open-market transactions can constitute market manipulation if done with manipulative intent. ${ }^{16}$

The Second Circuit has been the leader in identifying the elements of an open-market manipulation claim. These include profit or other personal gain to the alleged manipulator, deceptive intent, domination in the market for the shares at issue, and the economic reasonableness of the allegedly fraudulent transaction. ${ }^{17}$ The market-domination factor looks to the percentage of trades carried out by any one actor and views this percentage "in light of the time period involved and other indicia of manipulation." 18 The United States District Court for the Southern District of New York has interpreted "other indicia" to include such factors as whether the domination is alleged either over a long period or instead over a shorter period in conjunction with other fraudulent actions..$^{19}$ Despite these attempts to clarify the standards of an open-market manipulation claim, this doctrine has remained largely absent from federal securities litigation. However, as discussed below in Part III.A, the advent of aggressive HFT strategies may provide the opening needed for fuller development of this theory.

\section{Market manipulation under $\S 9$.}

An alternative to claims brought under $\S 10(\mathrm{~b})$ are claims brought under $\S 9$ of the Exchange Act. ${ }^{20}$ While $\S 9$ expressly addresses the manipulation of securities prices, it does not include the reliance requirement present in $\S 10(\mathrm{~b})$ and Rule $10 \mathrm{~b}-5 . .^{21}$ However, $\S 9$ does require a showing of specific intent "for the purpose of inducing the purchase or sale of such security by others" or "for the purpose of creating a false or misleading

15 GFL Advantage Fund, Ltd v Colkitt, 272 F3d 189, 205 (3d Cir 2001).

16 See Securities and Exchange Commission v Masri, 523 F Supp 2d 361, 368 (SDNY 2007), citing Markowski $v$ Securities and Exchange Commission, 274 F3d 525, 527-28 (DC Cir 2001), and quoting HR Rep No 73-1383 at 20 (cited in note 7) (stating that a trader's transactions "become unlawful only when they are made for the purpose of raising or depressing the market price") (quotation marks omitted).

17 See United States v Mulheren, 938 F2d 364, 370-72 (2d Cir 1991).

18 Id at 371.

19 See In re College Bound Consolidated Litigation, 1995 WL 450486, *6 (SDNY).

2015 USC $\S 78 \mathrm{i}$.

21 See Adam C. Pritchard, Stoneridge Investment Partners v Scientific-Atlanta: The Political Economy of Securities Class Action Reform, 2008 Cato S Ct Rev 217, 235. 
appearance" of market activity. ${ }^{22}$ This standard has proven challenging for plaintiffs to meet, given the many different factors that can affect a security's price. ${ }^{23}$ Consequently, while courts often look to $\S 9$ for guidance as to the types of behaviors and results that Congress intended to prohibit with the Exchange Act, plaintiffs and prosecutors rarely rely on $\S 9$ when bringing manipulation proceedings. ${ }^{24}$

\section{B. The Fraud-on-the-Market Presumption of Reliance}

Of the theories of liability discussed above, claims of fraudulent misrepresentation brought under $\S 10(\mathrm{~b})$ and Rule 10b-5 have been the most prevalent. However, such claims are not without procedural hurdles of their own. Specifically, the reliance prong of Rule $10 \mathrm{~b}-5$ tends to create difficulties for plaintiffs in securities-fraud class actions. Because of the potential for both negative publicity and frivolous class actions brought solely to induce settlement, large public companies have become particularly wary of letting securities-fraud class actions proceed to trial, and consequently class certification has become the "key legal battleground" of these cases. ${ }^{25}$

A class can be certified under FRCP 23 only if the plaintiffs have met the requirements of numerosity, commonality, typicality, and adequacy. ${ }^{26}$ Securities class actions are typically brought under FRCP 23(b)(3), which additionally requires that "questions of law or fact common to class members predominate over any questions affecting only individual members, and that a class action is superior" to other methods of adjudication. ${ }^{27}$ However, without a classwide determination of reliance, "individual questions of reliance would predominate and claims of multiple investors could not be aggregated in a class action" under FRCP $23(b)(3) .{ }^{28}$ "[R] equiring proof of individualized reliance" from

2215 USC $§ 78 \mathrm{i}$.

23 See Pritchard, 2008 Cato S Ct Rev at 235 (cited in note 21).

24 See Multer, $39 \mathrm{Sec}$ Reg L J at 106 (cited in note 12).

25 Larry Bumgardner, The Fraud-on-the-Market Method of Proving Securities Fraud: Indispensable Theory, or Device to Induce Settlements?, $10 \mathrm{~J}$ Global Bus Mgmt 121,121 (2014).

26 See FRCP 23(a).

27 FRCP 23(b)(3). Securities class actions seeking monetary damages cannot be brought under FRCP 23(b)(2) as they do not seek declaratory or injunctive relief, and typically are not proper under FRCP 23(b)(1) as there is rarely a risk of "inconsistent or varying adjudications" or harm to absent class members. FRCP 23(b)(1)-(2).

28 Barbara Black, Behavioral Economics and Investor Protection: Reasonable Investors, Efficient Markets, 44 Loyola U Chi L J 1493, 1497 (2013). 
every plaintiff class member would prevent many suits from proceeding; $; 9$ because the many shareholders in a putative class probably bought or sold their shares "at various times, and for different reasons, [] the reliance issue could vary greatly from case to case." 30 Preventing class certification in effect prevents plaintiffs from getting these claims into court entirely, as individualized damages are almost always too low to offset litigation costs. ${ }^{31}$

To avoid this problem, plaintiffs can-in appropriate casessatisfy the reliance prong by asserting the fraud-on-the-market presumption of reliance rather than alleging direct reliance on the defendant's misrepresentations. While the fraud-on-themarket presumption emerged in Basic Inc $v$ Levinson $^{32}$ as a "judicially created doctrine designed to implement a judicially created cause of action," ${ }_{33}$ it has since become a "substantive doctrine of federal securities-fraud law." 34 This Section explains the framework of the presumption, discusses litigation regarding the presumption's predicates, and then examines the Supreme Court's most recent case addressing this issue.

\section{Asserting and rebutting the fraud-on-the-market} presumption.

The fraud-on-the-market presumption of reliance is based on the hypothesis that in an efficient, well-developed market, all public information about a company is reflected in the company's stock price and that "[a]n investor who buys or sells stock at the price set by the market does so in reliance on the integrity of [the market] price." ${ }^{35}$ When the presumption is available, plaintiffs can assert that there was a fraud on the market and eliminate the need to prove individual reliance with respect to certain federal securities-law claims-a need that would otherwise prohibit class certification. ${ }^{36}$ In an efficient market, the effects of public information are reflected in the market price of the

29 Halliburton Co v Erica P. John Fund, Inc, 134 S Ct 2398, 2407-08 (2014) ("Halliburton II"), quoting Basic Inc v Levinson, 485 US 224, 242 (1988) (quotation marks omitted).

30 Bumgardner, $10 \mathrm{~J}$ Global Bus Mgmt at 122 (cited in note 25).

31 See id.

32485 US 224 (1988).

33 Halliburton $I I, 134 \mathrm{~S}$ Ct at 2411.

34 Amgen, $133 \mathrm{~S} \mathrm{Ct}$ at 1193.

35 Basic, 485 US at 247.

36 See Bumgardner, $10 \mathrm{~J}$ Global Bus Mgmt at 121 (cited in note 25). 
stock-making the plaintiffs' reliance on the market price essentially equivalent to their direct reliance on the defendant's misrepresentations. ${ }^{37}$ To invoke this presumption, plaintiffs must prove that: "(1) the alleged misrepresentations were publicly known, (2) they were material, (3) the stock was traded in an efficient market, and (4) the plaintiff traded the stock between when the misrepresentations were made and when the truth was revealed" 38 (which is often done via corrective disclosures to, or adjustments of, earnings estimates).

Fulfilling these predicates creates a presumption that the alleged misrepresentations affected the market price, which defendants can rebut in several ways. Typically, a rebuttal consists of "[a]ny showing that severs the link between the alleged misrepresentation and either the price received (or paid) by the plaintiff, or his decision to trade at a fair market price." ${ }^{39}$ Such a showing must also establish the absence of "price impact," defined as the misrepresentation's distortion of the security's price such that the resulting price differs from what it would have been but for the misrepresentation. ${ }^{40}$ After the Supreme Court's recent decision in Halliburton Co $v$ Erica P. John Fund, Inc ${ }^{41}$ ("Halliburton II"), defendants may introduce priceimpact evidence at the class-certification stage for the purpose of rebutting the presumption. ${ }^{42}$ Defendants can further rebut the presumption by showing that the plaintiffs knew of the omitted or misstated facts, ${ }^{43}$ or by showing that the plaintiffs would have traded at the same price even if they had been aware of the alleged misrepresentation. ${ }^{44}$ Similarly, by introducing evidence that the market price did not change in response to a particular representation, defendants can imply that either the misrepresentation was inconsequential or the market was inefficient. ${ }^{45}$ In

37 See Basic, 485 US at 241-42.

38 Halliburton $I I, 134 \mathrm{~S} \mathrm{Ct}$ at 2413.

39 Basic, 485 US at 248.

40 Halliburton $I I, 134 \mathrm{~S} \mathrm{Ct}$ at 2416-17.

$41 \quad 134$ S Ct 2398 (2014).

42 Id at 2413-14.

43 See, for example, Zobrist $v$ Coal-X, Inc, 708 F2d 1511, 1517-19 (10th Cir 1983) (finding no reliance because the plaintiff was considered knowledgeable of warnings contradicting the misrepresentations).

44 See, for example, Gianukos $v$ Loeb Rhoades \& Co, 822 F2d 648, 656 (7th Cir 1987) (finding no reliance because the plaintiffs' decision to trade was based on insider information rather than on the market price).

45 See, for example, Halliburton II, $134 \mathrm{~S} \mathrm{Ct}$ at 2415 (noting that defendants may introduce evidence "to refute the plaintiffs' claim of general market efficiency"). 
certain situations, defendants can also assert a "truth-on-themarket" defense, which refutes the materiality of the misleading disclosure by showing that corrective information in the marketplace countered any negative effects of the original statement. ${ }^{46}$ If the presumption is successfully rebutted, plaintiffs must instead prove reliance on an individual basis, which poses substantial difficulties to proceeding as a class action. ${ }^{47}$

2. Litigation regarding the fraud-on-the-market predicates.

The intricacies and specific requirements of the fraud-onthe-market predicates have been the subject of much litigation in the years since Basic. This Section addresses the leading cases involving the two most contentious factors: market efficiency and price impact, which underlie the misrepresentation, materiality, and loss-causation predicates. Successfully proving either of these requirements often involves economics-heavy expert reports, and both have been discussed often in recent years.

a) Cammer $\mathrm{v}$ Bloom:48 determining market efficiency. Generally, a determination of market efficiency examines whether the market price for a particular security responds to material public information. ${ }^{49}$ The efficiency prong of the Basic presumption is based on the efficient capital markets hypothesis, a controversial topic in the economics literature. ${ }^{50}$ This hypothesis asserts that in an efficient market, a security's price fully reflects all publicly available information regarding a company and its stock because informed traders quickly notice and

46 See, for example, Kaplan $v$ Rose, 49 F3d 1363, 1376-77 (9th Cir 1994) (finding a genuine issue of fact as to whether the information available in the market was "transmitted to the public with a degree of intensity and credibility sufficient to effectively counterbalance [the defendant's] allegedly misleading statements") (quotation marks omitted).

47 See Halliburton $I I, 134 \mathrm{~S}$ Ct at 2406.

48711 F Supp 1264 (D NJ 1989).

49 See id at 1273 n 11. See also Eugene F. Fama, Efficient Capital Markets: A Review of Theory and Empirical Work, 25 J Fin 383, 383 (1970) (defining "efficient stock market" as a market in which stock prices reflect all potentially available information that is relevant to the economic value of the stocks).

50 The Sveriges Riksbank Prize in Economic Sciences in Memory of Alfred Nobel 2013 was awarded to "the leading proponents of opposing views" of the hypothesis-"one, the theory's author, the other, its most influential critic." Brief for Former SEC Commissioners and Officials and Law Professors as Amici Curiae Supporting Petitioners, Halliburton Co v Erica P. John Fund, Inc, Docket No 13-317, *6 (US filed Jan 6, 2014) (available on Westlaw at 2014 WL 69391) ('Law Professors' Brief') (quotation marks omitted). 
take advantage of pricing errors - thereby nudging the price toward its proper (most efficient) level. ${ }^{51}$

In determining market efficiency, most courts rely on the factors laid out in Cammer: the average weekly trading volume, the number of analysts following the stock, the number of market makers ${ }^{52}$ and arbitrageurs, ${ }^{53}$ the issuing company's eligibility to file a Form S-3 registration statement, ${ }^{54}$ and the cause-andeffect relationship between corporate events or financial releases and the stock price. ${ }^{55}$ Courts disagree about whether all of these factors must be satisfied, which are the most important, which should be the most heavily weighted, and what the appropriate thresholds are for satisfying each factor. ${ }^{56}$ At a minimum, however, most courts agree that plaintiffs must prove that they traded on an "open and developed" or a "well-developed" market. ${ }^{57}$ Later courts have interpreted "developed markets" as generally referring to large, impersonal, actively traded markets, in contrast to "undeveloped markets" such as "thin markets and markets for new offerings and restricted resale securities." ${ }^{8}$

Through litigation, courts have determined that certain markets and exchanges should be considered presumptively efficient. Such markets include large national exchanges like the NYSE, as these exchanges are "generally populated by stocks that are closely watched by analysts and that trade at a high volume." 59 The Cammer court even went so far as to say that this

51 See Ronald J. Gilson and Reinier Kraakman, The Mechanisms of Market Efficiency Twenty Years Later: The Hindsight Bias, 28 J Corp L 715, 723 (2003) (explaining the history and assumptions of the efficient-markets hypothesis).

52 "Market makers" are dealers who hold themselves out as willing to trade securi. ties for their own accounts on a "regular or continuous basis," effectively creating a market for the security. 15 USC § 78c(a)(38).

53 "Arbitrageurs" are traders who identify and eliminate disparities between the price and the perceived market value of the security. See Sullivan \& Long, Inc v Scattered Corp, 47 F3d 857, 862 (7th Cir 1995).

54 Form S-3 'is the 'short form' used by eligible domestic companies to register securities offerings" and helps companies avoid costs associated with filing amendments to registration statements. Securities and Exchange Commission, Revisions to the Eligibility Requirements for Primary Securities Offerings on Forms S-3 and F-3, 72 Fed Reg 73534, 73534-35 (2007), amending 17 CFR §§ 230, 239.

55 See Cammer, 711 F Supp at 1287.

56 See, for example, Donald C. Langevoort, Basic at Twenty: Rethinking Fraud on the Market, 2009 Wis L Rev 151, 154, 167 (noting that " $t \mathrm{t}]$ he law is confused, and in flux," and that "[t]he jumble [in determining efficiency] is evident").

57 Basic, 485 US at 241, 244, 246-48 (quotation marks omitted).

58 Cammer, 711 F Supp at 1277.

59 Local 703, I.B. of T. Grocery \& Food Employees Welfare Fund v Regions Financial Corp, 762 F3d 1248, 1257 (11th Cir 2014). See also In re DVI, Inc Securities 
presumption of efficiency should "probably [be] conditional for class determination."60 For securities trading on these exchanges, defendants can rebut the presumption of market efficiency by showing that the security in question was inactively traded or unresponsive to new information. ${ }^{61}$ At the very least, such markets have all the characteristics necessary to satisfy Basic's "open and developed" requirement.62

b) The Halliburton cases: loss causation and price impact. The fraud-on-the-market theory was again thrust to the forefront of the Supreme Court's securities jurisprudence in the partner cases Erica P. John Fund, Inc v Halliburton $\mathrm{Co}^{63}$ ("Halliburton I") and Halliburton II. The Erica P. John Fund, as the lead plaintiff in a putative class action of similarly situated Halliburton investors, alleged that over a period of two and a half years Halliburton made a series of misrepresentations about its potential liability in an ongoing asbestos litigation, including overstatements of its expected revenue from construction contracts and the anticipated benefits of a future merger. ${ }^{64}$ Halliburton later made a number of corrective disclosures that allegedly caused a drop in its stock price and a corresponding injury to investors. ${ }^{65}$ The suit's procedural history involved two trips to the Supreme Court. Halliburton I, decided in 2011, involved a determination of whether class certification requires proof of loss causation (the Court held that it does not) ${ }^{66}$ but did not address any other question involving the fraud-on-the-market presumption or rebuttal thereof. The case was remanded to the district court for further proceedings, which eventually resulted in Halliburton II in 2014.67

Before evaluating the Court's decision in Halliburton II, it is important to note that the first three predicates for invoking

Litigation, $639 \mathrm{~F} 3 \mathrm{~d}$ 623, 634 (3d Cir 2011) ("[T]he listing of a security on a major exchange such as the NYSE or the NASDAQ weighs in favor of a finding of market efficiency.").

60 Cammer, 711 F Supp at 1292.

61 See id. See also Alan R. Bromberg, Lewis D. Lowenfels, and Michael J. Sullivan, 5 Bromberg and Lowenfels on Securities Fraud § 7.484, 7-928 to -929 (Thomson Reuters 2d ed 2014) (noting that such markets include the NYSE, the American Stock Exchange, the Chicago Board Options Exchange, and the NASDAQ National Market System).

62 Cammer, 711 F Supp at 1285-87.

$63131 \mathrm{~S} \mathrm{Ct} 2179$ (2011).

64 Halliburton II, 134 S Ct at 2405-06.

65 Id.

66 Halliburton I, $131 \mathrm{~S} \mathrm{Ct}$ at 2184-86.

67 Halliburton II, $134 \mathrm{~S} \mathrm{Ct}$ at 2406. 
the fraud-on-the-market presumption-publicly known misrepresentations, materiality, and trading on an efficient market-speak to price impact. "Price impact" generally refers to whether the market specifically responded to information about the exact issuer at the exact time that the information became publicly available.68 "In the absence of price impact, Basic's fraud-on-the-market theory and presumption of reliance collapse" because the fundamental premise of the presumption is that the alleged misrepresentation was reflected in the market price at the time of the relevant transaction. ${ }^{69}$ Before Halliburton II, there was no doubt that defendants could introduce priceimpact evidence at the class-certification stage "so long as it [was] for the purpose of countering a plaintiff's showing of market efficiency, rather than directly rebutting the presumption." Indeed, plaintiffs frequently introduce price-impact evidence in connection with event studies-expert reports and regression analyses showing the impact, if any, of "pertinent publicly reported events" or information on the market price of the defendant's stock..$^{71}$ The Court therefore could not find a good reason to prevent defendants from similarly submitting price-impact evidence prior to class certification. ${ }^{72}$

However, the precise issue in Halliburton II was the purpose for which defendants may introduce such evidence at the class-certification stage. Halliburton sought to introduce this evidence for the purpose of rebutting the presumption entirely; as plaintiffs, the Erica P. John Fund and other institutional investors wanted the evidence limited to the issue of market efficiency such that the price-impact issue would be decided after class certification at the merits stage. ${ }^{73}$ Chief Justice John Roberts, writing for the Court, noted that it "makes no sense" to keep defendants from relying on the same evidence prior to class certification for the particular purpose of rebutting the presumption altogether, and that such a restriction would have unnecessarily costly results. ${ }^{74}$

68 Halliburton $I, 131 \mathrm{~S}$ Ct at 2187.

69 Halliburton II, $134 \mathrm{~S} \mathrm{Ct}$ at 2414 (citations omitted).

70 Id at 2414-15.

71 Id at 2415.

72 Id.

73 Halliburton II, $134 \mathrm{~S} \mathrm{Ct}$ at 2415.

74 Id at $2415-16$. 


\section{Halliburton II s impact on securities class actions.}

Halliburton II has changed the landscape of securities-fraud class actions. As defendants are now allowed to introduce evidence at the class-certification stage for the purpose of rebutting the fraud-on-the-market presumption entirely, it is likely that more event studies will make their way into securities-fraud litigation. ${ }^{75}$ In addition, because the defendant's introduction of this evidence is no longer cabined to refuting the plaintiffs' showing of market efficiency, event studies will presumably attack other prongs of the presumption as well. Of the established predicates, loss causation seems like an especially vulnerable target-indeed, there is a well-developed body of literature examining the impact that event studies have on proving or disproving showings of loss causation. ${ }^{76}$

Event studies are a type of expert report, often in the form of a statistical regression analysis, that examine the effect of an event on a dependent variable such as the price of a security. ${ }^{77}$ These analyses seek to measure the impact of an event on a given security's price; the procedures they follow can be generalized into four broad steps. First, the expert identifies the event that caused investors to change their expectations about the security's value and determines the period of time in which the public learned of the event. ${ }^{78}$ Second, the expert measures the security's value for that period, typically by looking to the returns on the day of the event. Third, the expert determines whether the event affected the security's value by comparing that day's returns to the security's expected returns for the same period. This step involves implementing a variety of statistical and economic models to predict the price of the security and often compares its performance to other related or comparable securities. Finally,

75 See generally Kristin Feitzinger and Amir Rozen, Halliburton II and the Importance of Economic Analysis Prior to Class Certification (Cornerstone, 2014), archived at http://perma.cc/H7U2-SXYC ("Going forward, [event studies] ... will [] be key tools for defendants seeking to establish prior to class certification that an alleged misrepresentation did not impact price.").

76 See, for example, Michael J. Kaufman and John M. Wunderlich, Regressing: The Troubling Dispositive Role of Event Studies in Securities Fraud Litigation, 15 Stan J L Bus \& Fin 183, 208-10 (2009) (noting that event studies are now an "essential element" of showing loss causation in a securities-fraud case).

77 See Jay W. Eisenhofer, Geoffrey C. Jarvis, and James R. Banko, Securities Fraud, Stock Price Valuation, and Loss Causation: Toward a Corporate Finance-Based Theory of Loss Causation, 59 Bus Law 1419, 1425 (2004).

78 These events are typically corporate announcements, such as earnings restatements or talks of mergers and acquisitions. 
the expert estimates the event's effects and determines whether the abnormal returns are statistically significant and causally related to the event. At this stage, the expert must also determine whether there were other events that might have affected the security's value during the same period. ${ }^{79}$

Even with this established framework, however, the introduction of more event studies at the class-certification stage seems unlikely to systematically tip the scale in favor of either plaintiffs or defendants. Because of the parties' competing incentives, the introduction of such evidence is likely to turn into a battle of the experts. Plaintiffs' experts will define the fraud as broadly as possible so that any and all of the company's announcements that potentially harmed the stock price will be considered related to the fraud; defendants' experts will attempt to parse every announcement made by a company in order to isolate factors that negatively impacted the stock price but were not related to the alleged fraud. ${ }^{80}$ As a result of this potential battle of the experts, courts and juries will have to make their own determinations regarding which expert is correct in each situation-leading to potentially unpredictable outcomes. ${ }^{81}$

In the wake of Halliburton II, it is not yet evident whether the number of event studies introduced at the class-certification stage will increase or whether these studies will push courts in either a pro-plaintiff or a pro-defendant direction. One early study has found that the number of class-certification motions granted has dropped; however, this study also found that the first three post-Halliburton II rulings on motions to dismiss filed in Rule 10b-5 class actions each considered the defendants' price-impact arguments while ruling for the plaintiffs and granting class certification. ${ }^{82}$ While three cases are too few to indicate

79 For a more in-depth explanation and analysis of these steps, see Sanjai Bhagat and Roberta Romano, Event Studies and the Law: Part I; Technique and Corporate Litigation, 4 Am L \& Econ Rev 141, 143-47 (2002).

80 See Eisenhofer, Jarvis, and Banko, 59 Bus Law at 1427-28 (cited in note 77).

81 See In re Thornburg Mortgage, Inc Securities Litigation, 912 F Supp 2d 1178, 1242 (D NM 2012), quoting In re Warner Communications Securities Litigation, 618 F Supp 735, 744 (SDNY 1985) ("Damages in this case, as is common in securities class actions, would likely have been reduced to a 'battle of the experts,' and 'it is virtually impossible to predict with any certainty which testimony would be credited."'). See also In re Cendant Corp Litigation, 264 F3d 201, 253-54 (3d Cir 2001) (noting that a court's choice between two competing expert opinions is "intensely fact-based" and "within the purview of the District Court's discretion").

82 Renzo Comolli and Svetlana Starykh, Recent Trends in Securities Class Action Litigation: 2014 Full-Year Review *19-21 (NERA, Jan 20, 2015), archived at 
a trend, it is possible that the rate at which motions for class certification are granted post-Halliburton II will be higher than the 75 percent rate at which courts granted such motions from 2000 through the end of $2014 .^{83}$ It remains to be seen whether this development will continue, and if it does, whether an increase in grants of class certification will lead to a corresponding increase in adjudication on the merits for plaintiffs.

\section{HFT TODAY: NEW TECHNOLOGIES AND NEW LITIGATION CHALLENGES}

Against this backdrop, HFT raises additional problems and questions regarding whether and how the federal securities laws should apply to circumstances involving this type of trading. HFT is very technical, and as such, any discussion of the law regarding HFT benefits from an understanding of HFT's mechanics. Part II.A presents a basic overview of the strategies behind HFT, as well as some of the benefits and criticisms that have been identified in early literature. Part II.B briefly summarizes the heated and extensive debate over HFT's impact on market efficiency. Part II.C then provides an overview of SEC regulatory activity regarding HFT and current litigation involving HFT.

\section{A. The Basics of HFT}

While electronic trading has become the status quo in the marketplace, HFT takes computerized trading several steps further and involves strategies that are much more technical than merely pressing "enter" to submit an order. Generally, highfrequency traders use computer codes to submit rapid-fire bids and offers, which create short-term markets and enable traders to realize marginal profits on price imbalances. ${ }^{84}$ Firms that utilize HFT algorithms obtain split-second advantages over firms that are still using conventional computerized trading. Supporters say this advantage improves market liquidity, while critics argue that these advantages can, among other consequences, mask market manipulation and destroy the structure of capital

http://perma.cc/8US6-MHQ5. These three Rule 10b-5 class actions are: McIntire $v$ China MediaExpress Holdings, Inc, 38 F Supp 3d 415, 434 (SDNY 2014); Aranaz $v$ Catalyst Pharmaceutical Partners Inc, 302 FRD 657, 672 (SD Fla 2014); and Wallace v Intralinks, 302 FRD 310, 317 (SDNY 2014).

83 Comolli and Starykh, Recent Trends at *19 (cited in note 82).

84 See Frank J. Fabozzi, Sergio M. Focardi, and Caroline Jonas, High-Frequency Trading: Methodologies and Market Impact, 19 Rev Fut Mkts 7, 8-9 (special issue 2011). 
markets. ${ }^{85}$ Firms employing HFT strategies often trade on open, public markets including the NYSE and NASDAQ; recent studies estimate that HFT now accounts for over 70 percent of all trades in US equity markets. ${ }^{86}$ It is important to note at the outset that currently most HFT is done by banks' and trading firms' in-house proprietary accounts-that is, on behalf of banks or firms rather than on behalf of outside, individual investors. ${ }^{87}$

HFT is a subset of algorithmic trading, which generally relies on computers to enter trading orders and uses algorithms to determine various aspects of the orders such as timing, price, and quantity. Behavior involving HFT is roughly classified as one of two types: market-making activities, in which traders hold themselves out as willing to trade in order to create and profit from the demand for a security; or more aggressive HFT strategies like statistical arbitrage, in which traders seek to profit by trading on the miniscule price discrepancies identified by statistical models. ${ }^{88}$ In a recent concept release, the SEC identified five general characteristics that are often attributed to HFT, regardless of the specific type of strategy employed:

(1) The use of extraordinarily high-speed and sophisticated computer programs for generating, routing, and executing orders; (2) use of co-location services and individual data feeds offered by exchanges and others to minimize network and other types of latencies; (3) very short time-frames for establishing and liquidating positions; (4) the submission of numerous orders that are cancelled shortly after submission; and (5) ending the trading day in as close to a flat position as possible (that is, not carrying significant, unhedged positions overnight). ${ }^{89}$

The various technical strategies used in HFT rely on different sources of information, statistical comparisons, and types of

85 See Nathan D. Brown, Comment, The Rise of High Frequency Trading: The Role Algorithms, and the Lack of Regulations, Play in Today's Stock Market, 11 Appalachian J L 209, 210 (2012).

86 See, for example, Fabozzi, Focardi, and Jonas, 19 Rev Fut Mkts at 23 (cited in note 84).

87 See Gary Shorter and Rena S. Miller, High-Frequency Trading: Background, Concerns, and Regulatory Developments ${ }^{*} 6$ \& n 19, 13 (Congressional Research Service, June 19, 2014), archived at http://perma.cc/QZ6K-Y4LR.

88 See X. Frank Zhang, High-Frequency Trading, Stock Volatility, and Price Discov. ery *5 (December 2010), archived at http://perma.cc/N25V-BB9D.

89 Securities and Exchange Commission, Concept Release on Equity Market Structure, 75 Fed Reg 3594, 3606 (2010). 
algorithms. ${ }^{90}$ When employing "arbitrage strategies," algorithms correlate prices among securities trading on different markets and trade off the imbalances in those prices, which can be as small as a fraction of a penny.91 In "pairs trading," programs look at a correlation between the securities of two similar companies (for example, Coca-Cola and Pepsi) and trade on the movement of one or the other security-if the price of one moves up, there is an expectation that the other will move up as well.92 A variation of pairs trading involves "cross-asset pairs trading," in which algorithms examine the correlation between a derivative and its underlying asset. ${ }^{93}$ "Short-term statistical arbitrage" is yet another, more complex variation of pairs trading, which focuses on the inefficient pricing of securities as identified from statistical models. ${ }^{94}$ Traders can also use a strategy of "volatility trading," in which algorithms trade on fluctuations in a security's price rather than on the magnitude of the price movement. ${ }^{95}$

Finally, "liquidity detection" has emerged as one of the most controversial of these and other HFT strategies. In employing this strategy, traders use algorithms to "attempt to identify and profit from the actions of other large traders." 96 By examining an aggregate set of data points from multiple exchanges, these algorithms identify the existence of larger, hidden orders or traders attempting to enter or exit positions. For example, when a small order is filled quickly (an "iceberg order"), algorithms might infer that there is a large order behind it and base their

90 This list of strategies is not exhaustive but instead provides background regarding some of the most popular strategies.

91 See Andrew J. Keller, Note, Robocops: Regulating High Frequency Trading after the Flash Crash of 2010, 73 Ohio St L J 1457, 1467 (2012).

92 See Cristina McEachern Gibbs, Breaking It Down: An Overview of HighFrequency Trading (Wall Street \& Technology, Sept 29, 2009), archived at http://perma.cc/9DP5-3CLA.

93 See Michael Chlistalla, High-Frequency Trading: Better than Its Reputation? *3 (Deutsche Bank Research, Feb 7, 2011), archived at http://perma.cc/DCF3-BW5N.

94 See Gibbs, Breaking It Down (cited in note 92).

95 See id. For this strategy, it matters more that a security's price changes frequently; it is less important that a stock has increased or decreased in value from open to close of trading.

96 Matt Prewitt, Note, High-Frequency Trading: Should Regulators Do More?, 19 Mich Telecomm \& Tech L Rev 131, 135-36 (2012). Flash orders must still satisfy Regulation NMS, which requires that orders be offered at the National Best Bid and Offer price - that is, at the best available ask price when buying and at the best available bid price when selling. Securities and Exchange Commission, Regulation NMS, 70 Fed Reg 37496, 37501-02 (2005). See also Lawrence Harris and Ethan Namvar, The Economics of Flash Orders and Trading *4 (Jan 15, 2011), archived at http://perma.cc/SN49-MHSB. 
trading accordingly. ${ }^{97}$ Liquidity detection can also be based on "flash orders": when an investor places an order and there are no apparent sellers, the exchange might "flash" the order to certain traders. ${ }^{98}$ Potential sellers who receive the flash can see the buy order and respond with their own order to execute against and in competition with the flashed buy order; high-frequency traders will beat slower investors to these trades and may reap sizable profits. ${ }^{99}$

Proponents of HFT have highlighted several perceived advantages of these strategies. First and foremost is the opportunity to trade more shares more frequently: by exploiting marginal price differences (by the microsecond or nanosecond ${ }^{100}$ ), traders can make profits of cents or even fractions of a cent on each trade and still realize significant profits by the end of the day due to the extremely fast pace and high volume of shares traded. Additionally, HFT firms pay fees to purchase two distinct advantages from exchanges: co-location services, which allow traders to place their computer servers a few feet from each exchange's servers; and increased speed of data transmission, such that data released through securities information processors will reach HFT firms faster than it will reach conventional computerized trading firms. ${ }^{101}$ As a result, HFT firms often receive data in as little as 1 microsecond, whereas it takes approximately 1,500 microseconds for the same data to reach a traditional computerized trader. ${ }^{102}$

However, HFT is certainly not without its critics. In general, electronic trading requires traders to post a buy or sell order that a computer then matches with a corresponding sell or buy order on the other end of the trade. Provided that there is an

97 See Zhang, High-Frequency Trading at *9 (cited in note 88).

98 See Harris and Namvar, The Economics of Flash Orders at *2 (cited in note 96).

99 See Securities and Exchange Commission, Fact Sheet: Banning Marketable Flash Orders (Sept 17, 2009), archived at http://perma.cc/6FNY.RUXG. When the SEC first addressed flash orders in 2009, it estimated the length of the flash at "one second or less." Id. Recent estimates hover in the range of 30 to 150 milliseconds. See Harris and Namvar, The Economics of Flash Orders at *4 (cited in note 96).

100 A microsecond is one millionth $\left(10^{-6}\right)$ of a second; a nanosecond is one billionth $\left(10^{-9}\right)$ of a second. By way of comparison, estimates of the time it takes to blink an eye range from 100,000 to 400,000 microseconds; 1 microsecond is to 1 second as 1 second is to 11.574 days. See Second Consolidated Amended Complaint for Violation of the Federal Securities Laws, City of Providence v BATS Global Markets, Inc, Civil Action No 14. 2811, *27 n 18 (SDNY filed Sept 2, 2014) ("Providence Amended Complaint").

101 See Class Action Complaint, Lanier v BATS Exchange, Inc, Civil Action No 143745, *19-20 (SDNY filed May 23, 2014) ("Lanier Complaint").

102 See id at *20-24. 
acceptable match, the trade is executed. By speeding up the rates at which orders are posted and matched and by increasing the volume of posted orders, HFT adds uncertainty to the traditional electronic-trading mechanism. ${ }^{103}$ Critics of HFT have emphasized the potential opportunities for fraud that these new strategies introduce. Indeed, three types of fraud have been defined and generally accepted throughout the scholarship on HFT: "stuffing," in which high-frequency traders submit "an unwieldy number of orders" to congest the market and slow market access for non-high-frequency traders; "smoking," in which high-frequency traders post "alluring limit orders to attract slow traders" but then quickly reverse their orders "onto less generous terms, hoping to execute profitably against the incoming flow of slow traders' market orders"; and "spoofing," in which traders post and cancel orders to create a false appearance of market activity. 104

Further, one recent study has argued that the speed of HFT is in fact breaking down relationships between stocks and other types of securities. For example, in a constantly moving market, correlated financial products simply cannot move at exactly the same time when time is measured in increments that are too finely grained. ${ }^{105}$ Because the prices of correlated securities, such as futures contracts and their underlying commodities, are so intertwined and often predictive of each other, this breakdown leads to an increased opportunity for arbitrage for whichever firm is the fastest. ${ }^{106}$ Some scholars have advocated for slowing down the speed of HFT and imposing regulatory "speed limits" to help preserve these relationships; ${ }^{107}$ however, there have been no such regulations to date.

\section{B. The Impact of HFT on Market Efficiency}

Independent of the debate regarding the perceived advantages and disadvantages of HFT, much current scholarship focuses on the issue of market efficiency. Legal and economic

103 See Brown, Comment, 11 Appalachian J L at 218-19 (cited in note 85).

104 Bruno Biais and Paul Woolley, High Frequency Trading *8-9 (Mar 2011), archived at http://perma.cc/84AR-LQX8.

105 See Eric Budish, Peter Cramton, and John Shim, The High-Frequency Trading Arms Race: Frequent Batch Auctions as a Market Design Response *12-13 (June 4, 2015), archived at http://perma.cc/3SBL-4D63.

106 See id at *22.

107 See, for example, id at *52-54. 
scholarship regarding HFT's impact on market efficiency is extensive and inconclusive. On one side of the debate are scholars who believe that HFT adds to the efficiency of the market, or even that HFT cannot operate without an efficient market such that the presence of HFT is an indication of market efficiency. As HFT increases the speed at which trades occur, it also speeds up the valuation process that underlies the fraud-on-the-market presumption. ${ }^{108}$ In this way, HFT can be seen as increasing informational efficiency by enabling traders to process relevant information faster. ${ }^{109}$ The algorithms that process market orders from high-frequency traders will absorb not only publicly available information but also information about conventional traders' behavior faster than human traders will-resulting in a superior ability to predict price changes. ${ }^{110}$ Additional studies have provided evidence that HFT can reduce adverse selection costs (losses suffered by the buyer when a stock moves in the seller's favor immediately after the trade, and vice versa), narrow spreads between bid and ask prices, and increase the informational accuracy of price quotes-all of which may lead to increased efficiency in the marketplace. ${ }^{111}$ Indeed, at least one scholar has suggested that these features of HFT can be used to establish efficiency for the fraud-on-the-market presumption, noting that the criteria necessary to satisfy the efficient-market predicate should be "fairly easily met" given the "high-speed [and] high-turnover" of stocks when using this strategy.112

Much of this scholarship is based on the determination that the efficiency provided by HFT comes in the form of increased liquidity in the marketplace. ${ }^{113}$ Because high-frequency traders capitalize on gaps in trades (in terms of both timing and price), they introduce additional liquidity to the market. By seizing on the smallest of price discrepancies or time delays, HFT may help reduce volatility and improve the market's overall efficiency. One study of the effects of HFT on short-term price efficiency

108 See Part I.B.1.

109 See Biais and Woolley, High Frequency Trading at *14 (cited in note 104).

110 See id at $* 9$.

111 See Terrence Hendershott, Charles M. Jones, and Albert J. Menkveld, Does Algorithmic Trading Improve Liquidity?, 66 J Fin 1, 3-4 (2011).

112 Yesha Yadav, Beyond Efficiency in Securities Regulation *51-54 (Vanderbilt University Law School, Feb 24, 2014), archived at http://perma.cc/G32K-8DLW.

113 For example, one financial markets advisory group defines HFT as comprising "fully automated trading strategies that seek to benefit from market liquidity imbalances or other short-term pricing inefficiencies." Gibbs, Breaking It Down (cited in note 92$)$. 
has shown that aggressive HFT activity "improves price efficiency in the NASDAQ market by trading in the direction of permanent price changes and in the opposite direction of transitory pricing errors," which presumably normalizes prices over time. ${ }^{114}$ For example, arbitrage strategies that involve trading off of price discrepancies across different exchanges may have the effect of normalizing the price for any given security across the market nationwide. ${ }^{115}$ By trading on these inefficiencies and providing price correction in this manner, HFT arguably helps the market arrive at the proper price for the securities-thereby enhancing market efficiency.

However, a seemingly equal amount of literature reaches the opposite conclusion: that HFT instead introduces inefficiencies and errors into the market. In a recent speech, SEC Chair Mary Jo White noted that HFT can "sometimes detract from market quality, including the informational efficiency of prices."116 The fast-paced nature of HFT pressures traders to overvalue short-term information, which some scholars believe hinders the market's ability to accurately incorporate news into asset prices. 117 The sheer volume of trades that occur when HFT is introduced also leads to millions of price reversals in one day, creating instability and volatility in pricing. ${ }^{118}$ In addition, highfrequency traders add another middleman to each transaction by purchasing and then quickly selling the securities-and, critics argue, unnecessarily raising prices in the process. ${ }^{119}$

Yet another argument against HFT's tendency to increase efficiency relies on the effect that high-frequency traders have on traditional investors. Several studies, as well as commentary in Michael Lewis's influential book Flash Boys, suggest that

114 Staff of the Division of Trading and Markets, Equity Market Structure Literature Review: Part II; High Frequency Trading *10 (SEC, Mar 18, 2014), archived at http://perma.cc/9SFR-BKQM.

115 See note 91 and accompanying text.

116 Mary Jo White, Enhancing Our Equity Market Structure (SEC, June 5, 2014), archived at http://perma.cc/B8U8-AC4H (speech to Sandler O'Neill \& Partners, LP Global Exchange and Brokerage Conference).

117 See, for example, Kenneth A. Froot, David S. Scharfstein, and Jeremy C. Stein, Herd on the Street: Informational Inefficiencies in a Market with Short-Term Speculation, $47 \mathrm{~J}$ Fin 1461, 1481 (1992) (noting that short-term trading can have a "direct negative impact on the informational quality of asset prices").

118 See Zhang, High-Frequency Trading at *26 (cited in note 88) (suggesting that HFT hinders price discovery as it "pushes stock prices too far in the direction of earnings news, and, as a result, stock prices reverse in the subsequent months after the initial reaction").

119 See Michael Lewis, Flash Boys: A Wall Street Revolt 110 (Norton 2014). 
HFT harms traditional investors. ${ }^{120}$ In one study, a model that assumed perfect liquidity and no spread between bid and ask prices displayed an increase in market volatility on the introduction of HFT merely because of the increased speed of trades. ${ }^{21}$ The "abnormal trading profits" afforded to highfrequency traders in this scenario come at the expense of ordinary traders and exacerbate market inefficiency. ${ }^{122}$

In sum, despite the disagreement over HFT's effect on market efficiency, this debate coalesces around two major focal points. First, there is intense disagreement regarding HFT's impact on volatility in the market. While scholars in the proefficiency camp believe that the speed of HFT normalizes prices and decreases volatility over time, ${ }^{123}$ other studies suggest that the higher number of price reversals instead increases volatility and instability in prices. ${ }^{124}$ Second, scholars disagree about how HFT absorbs information into share prices and whether this absorption increases or decreases efficiency. Pro-efficiency arguments emphasize HFT's ability to incorporate information on both the company and trading behavior into the market faster, ${ }^{125}$ while anti-efficiency arguments focus on HFT's overvaluation of short-term information. ${ }^{126}$ To some extent, these differences likely reflect divergence in scholars' underlying value judgmentsbut they are presumably also the result of the vast uncertainty still surrounding HFT today.

\section{Current Legal Challenges to HFT}

The SEC has yet to promulgate any formal rules on the subject of HFT or any HFT-specific regulations, but it did increase its enforcement efforts after the Flash Crash of May 2010, when the Dow Jones Industrial Average suffered its largest intraday point loss-dropping 1,000 points in 5 minutes-and then recovered much of the loss just minutes later. ${ }^{127}$ While HFT is

120 Id at 171.

121 Robert A. Jarrow and Philip Protter, A Dysfunctional Role of High Frequency Trading in Electronic Markets *2-4 (Johnson School Research Paper Series, Mar 2011), archived at http://perma.cc/P5VE-DSEH.

122 Id at * 12 .

123 See note 114 and accompanying text.

124 See note 118 and accompanying text.

125 See notes 109-10 and accompanying text.

126 See note 117 and accompanying text.

127 See Brian Korn and Bryan Y.M. Tham, Why We Could Easily Have Another Flash Crash (Forbes, Aug 9, 2013), archived at http://perma.cc/84JP.KAL9. 
commonly blamed for causing the Flash Crash, some empirical research has indicated that, rather than triggering these events, HFT merely exacerbated preexisting price movement and market volatility. ${ }^{128}$

The SEC brought its first market manipulation case against an HFT firm on October 16, 2014, sanctioning Athena Capital Research for "marking the close"-that is, placing a large number of aggressive, rapid-fire trades in the final two seconds of almost every trading day during a six-month period-to push the closing prices of thousands of NASDAQ-listed stocks in the firm's favor. ${ }^{129}$ Athena's allegedly manipulative trading made up more than 70 percent of the total NASDAQ trading volume of the affected stocks in the seconds preceding the market close. The SEC argued that the firm's practices, including the use of algorithms to ensure that the firm's orders received priority over other orders that similarly traded on day-end price imbalances, constituted a manipulative or deceptive device pursuant to Rule $10 \mathrm{~b}-5 .{ }^{130}$ Athena ultimately "agreed to pay a $\$ 1$ million penalty and cease and desist from committing or causing any future violations of the securities laws." 131

Currently, the majority of litigation regarding HFT is in lawsuits against exchanges and alleges injury to traditional investors because of HFT. Many of these actions emerged after the publication of Flash Boys; in some cases, the language in the complaints seems largely cribbed from Lewis's book. The leading case is City of Providence $v$ BATS Global Markets, Inc, ${ }^{132}$ a currently pending class action brought on behalf of public investors who traded on one of several registered public stock exchanges

128 See, for example, Andrei Kirilenko, et al, The Flash Crash: The Impact of High Frequency Trading on an Electronic Market ${ }^{*} 18$ (Sept 24, 2014), archived at http://perma.cc/XT9P-WAH6. In addition, the DOJ recently brought criminal charges against an individual high-frequency trader, Navinder Singh Sarao, and his company for their activities in connection with the Flash Crash. See Criminal Complaint, United States of America $v$ Sarao, Criminal Action No 15-75, *21-24 (ND Ill filed Feb 11, 2015). The prosecutors in this case attributed "much of the blame" for the Flash Crash to Sarao. Nathaniel Popper and Jenny Anderson, Trader Arrested in Manipulation that Contributed to 2010 'Flash Crash' (NY Times, Apr 21, 2015), archived at http://perma.cc/CQZ4 $-7 \mathrm{QFV}$.

129 Securities and Exchange Commission, SEC Charges New York-Based High Frequency Trading Firm with Fraudulent Trading to Manipulate Closing Prices (Oct 16, 2014), archived at http://perma.cc/CN7J-AAXW.

$130 \mathrm{Id}$.

131 Id.

132 Complaint for Violation of the Federal Securities Laws, Civil Action No 14-2811 (SDNY filed Apr 18, 2014) ("Providence Complaint"). 
as well as in Barclays Liquidity Cross, the Barclays dark pool.133 The plaintiffs claim injury as a result of a course of business whereby the defendant brokerage firms and securities exchanges "employed devices, contrivances, manipulations and artifices to defraud in a manner that was designed to and did manipulate the U.S. securities markets and the trading of equities on those markets" in violation of $\$ \S 6(\mathrm{~b})$ and $10(\mathrm{~b})$ of the Exchange Act, among other provisions. ${ }^{134}$ The complaint highlights manipulative, self-dealing, and deceptive conduct in connection with the HFT strategies of electronic front running, rebate arbitrage, slow-market (or latency) arbitrage, spoofing, layering, and contemporaneous trading. ${ }^{135}$ Similar to the theory underlying the SEC's action against Athena Capital, the plaintiffs' central claim is that the HFT strategies allowed on the exchanges constituted market manipulation and fraud and deceit in violation of federal securities laws. This complaint was quickly followed by at least three more parallel cases in the Southern District of New York; ${ }^{136}$ at the writing of this Comment, the parties are awaiting a ruling on the defendants' motion to dismiss.

Another suit, also brought against the BATS Exchange, is distinct from City of Providence-type suits in that it relied entirely on state contract law and made a novel factual assertion

133 A "dark pool" is a private forum for trading securities in which traders do not reveal their identities and do not publicly display their transactions or the price at which those transactions are conducted. Dark pools are operated by broker-dealers and are regulated by the SEC and the Financial Industry Regulatory Authority. See Christopher Mercurio, Dark Pool Regulation, 33 Rev Ban \& Fin L 69, 69 (2013).

134 Providence Complaint at * 1 (cited in note 132). Section 6(b) of the Exchange Act outlines when an exchange may be registered as a national securities exchange. 15 USC $\S 78 \mathrm{f}(\mathrm{b})$.

135 In "electronic front running," HFT firms utilize preferred access to material trade data to identify and trade in front of large orders. "Rebate arbitrage" involves traders deciding which exchange to trade on based on the rebate paid to them by the exchanges for their trading. "Slow-market arbitrage," also known as "latency arbitrage," uses the speed of HFT to gain advantages in arbitraging price discrepancies in a particular security that trades simultaneously on different markets (this is the strategy used in the introductory hypothetical at the beginning of this Comment). "Spoofing" and "layering" involve inducing others to trade a security at a price not representative of actual supply and demand. Finally, "contemporaneous trading" involves entering both sides of a transaction at the same time in an attempt to cut losses. Providence Complaint at *3-4 (cited in note 132).

136 See generally Complaint for Violations of the Securities Laws, American European Insurance Co $v$ BATS Global Markets, Inc, Civil Action No 14-3133 (SDNY filed May 2, 2014); Complaint for Violations of the Securities Laws, Harel Insurance Co v BATS Global Markets, Inc, Civil Action No 14-3608 (SDNY filed May 20, 2014); Complaint for Violation of the Federal Securities Laws, Flynn v Bank of America Corp, Civil Action No 14-4321 (SDNY filed June 13, 2014). 
that read similarly to a common-law contracts claim. In Lanier $v$ BATS Exchange, Inc, ${ }^{137}$ the lead plaintiff brought suit individually and on behalf of subscribers who entered into contracts to receive electronic market data from the defendants. ${ }^{138}$ The com. plaint alleged that the exchanges transmitted market data to their HFT clients before they sent the same data to the securities information processor, which then aggregated the data and sent it to non-HFT subscribers (the plaintiffs). ${ }^{139}$ Choosing to base their claims on contract law rather than on federal securities laws, the plaintiffs alleged breach of contract, imposition of a constructive trust, and unjust enrichment from subscription fees and other fees from preferred data customers-fees that were paid by HFT firms to the exchanges. ${ }^{140}$ The court dismissed these claims, finding them preempted by a "comprehensive federal regulatory scheme."141 Similarly, a suit against the Chicago Mercantile Exchange and the Chicago Board of Trade alleges that both exchanges gave HFT firms advance access to order data in violation of the Commodities Exchange Act; ${ }^{142}$ this case is awaiting decision on a motion to dismiss.

$$
* * *
$$

While several of these suits allege a fraud on the marketplace, none invokes the fraud-on-the-market presumption of reliance in seeking class certification. The presumption may be a useful tool in bringing suit against high-frequency traders and may even be useful in the event that high-frequency traders begin to occupy the plaintiff classes of such actions as well. However, the short-term nature of HFT in conjunction with the complexity of its trading mechanisms creates interesting complications for this type of litigation, which are addressed in Part III.

137 Class Action Complaint, Civil Action No 14-3745 (SDNY filed May 23, 2014) ("Lanier Complaint").

138 Id at *5-6.

139 Id at ${ }^{*} 6-7$.

140 Id at *31-35.

141 Opinion and Order, Lanier $v$ BATS Exchange, Inc, Civil Action No 14-3745, *4 (SDNY filed Apr 28, 2015)

142 Class Action Complaint, Braman v CME Group, Inc, Civil Action No 14-2646, *1-2 (ND Ill filed Apr 11, 2014). 


\section{HFT TOMORROW: Proposed STRATEgIES AND SOLUTIONS}

HFT presents such unique strategies and introduces such peculiar questions to existing law that it is time for a reevaluation of traditional securities-law claims in light of these developments. The SEC has called HFT "one of the most significant market structure developments in recent years,"143 indicating that traditional evaluations of the speed and frequency of trading and the openness of markets should be reassessed. A textual comparison to the language of Basic itself indicates that this transformation of trading strategies no longer justifies the continued application of that decision to securities class actions without modifications that reflect the current state of securities markets. Basic referred to the "modern securities markets" as involving "millions of shares changing hands daily" and noted that those modern markets differed from "the face-to-face transactions contemplated by early fraud cases"; ${ }^{144}$ today, HFT differs in a similar magnitude from the "modern securities markets" of 1988. As such, it is time to reconsider the legal framework for assessing these claims. This Part presents possible solutions for some of the procedural problems identified above-including proof of price impact and reliance ${ }^{145}$-and proposes ways in which the Basic-era requirements for securities-fraud class actions should be tailored or altered in light of HFT.

In addition, there is reason to believe that as HFT gains traction in the market, an ever-increasing share of trades will be completed via HFT. Indeed, from 2004 to 2010, HFT increased from 13 percent of all foreign exchange trades to 30 percent and, by 2011, "account[ed] for about 60 percent of the seven billion shares that change hands daily on United States stock markets." 146 Large institutional investors engaged in trading for wealth-management purposes-including pension funds, such as the Erica P. John Fund, that are often lead plaintiffs in securities-fraud class actions-often do their trading on open exchanges like the NYSE and NASDAQ, and several commentators have noted that HFT might work against these longer-term investors while allowing traders who employ HFT strategies to

${ }_{143}$ Staff of the Division of Trading and Markets, Literature Review at *4 (cited in note 114).

144 Basic, 485 US at 243-44.

145 See Part I.B.1.

146 Tom C.W. Lin, The New Investor, 60 UCLA L Rev 678, 692 (2013) (quotation marks omitted). 
reap short-term benefits. ${ }^{147}$ While pension funds are not generally involved in HFT, other institutional investors have started using certain services offered by HFT firms, which presents an additional complication and yet another reason to reexamine these issues. ${ }^{148}$ With the continued growth of HFT, eventually even pension funds and other traditional, non-HFT institutional investors - who have important incentives to be activist investors and act as a check on corporate governance issues-will not be able to keep up with the pace of the market. ${ }^{149}$

Thus, courts deciding securities-fraud class actions will have to resolve the problem of how the different manners and mechanisms by which investors conduct trades affect their treatment in litigation. Courts will also have to face the procedural difficulty of identifying precisely which high-frequency traders and which HFT firms were present in the market to affect trading. Further, there may eventually be situations in which plaintiff classes of high-frequency traders seek to avail themselves of the securities laws. As there are currently no identifiable instances of such cases, this will be a novel situation if and when such plaintiffs come to court.

This discussion of HFT in litigation proceeds in two stages. First, Part III.A proposes a litigation strategy for plaintiffs bringing suit against high-frequency traders. After reviewing determinations of market efficiency in light of Halliburton II, Part III.A evaluates arguments made by the City of Providence plaintiffs and then puts forth a new litigation strategy based on existing theories of market manipulation. Second, Part III.B looks ahead to the day when investors that have acquired their shares via HFT seek to bring actions against corporations as issuers for Rule $10 \mathrm{~b}-5$ violations involving fraudulent misrepresentations. Part III.B then argues that, while high-frequency traders may have standing to sue because of the characteristics they share with short sellers, procedural difficulties in proving typicality and loss causation will likely prevent these suits from proceeding as class actions.

147 See, for example, Keller, Note, 73 Ohio St L J at 1468 (cited in note 91) (noting that certain HFT strategies use "speed and volume to earn consistent gains to the detriment of other market participants, mainly large institutional investors"); Fabozzi, Focardi, and Jonas, 19 Rev Fut Mkts at 34 (cited in note 84).

148 See Prewitt, Note, 19 Mich Telecomm \& Tech L Rev at 134 (cited in note 96).

149 See Charles R. Korsmo, High-Frequency Trading: A Regulatory Strategy, $48 \mathrm{U}$ Richmond L Rev 523, 560 (2014) (noting the fear that large non-HFT institutional investors will not be able to keep pace with the "heavy artillery" of HFT firms). 


\section{A. Bringing Suit against High-Frequency Traders}

The current perception of high-frequency traders, based on books like Flash Boys, paints these traders as villains seeking to manipulate the market for their own benefit. As such, lawsuits have been brought against, rather than by, such traders, and plaintiffs have often sought recourse under $\S 10(\mathrm{~b})$. Both misrepresentation claims and market manipulation claims under Rule $10 \mathrm{~b}-5$, however, require a showing of reliance. ${ }^{150}$ Consequently, plaintiffs in a FRCP 23(b)(3) class action will have to invoke the fraud-on-the-market presumption of reliance to certify their class, which includes a showing of market efficiency. If the fraud-on-the-market presumption is not available, plaintiffs will have to seek alternative forms of recovery, including but not limited to individual damages actions.

This Section addresses these issues in turn, beginning with Halliburton IT's likely effect on showings of market efficiency and next discussing the arguments raised by the parties in City of Providence. Finally, this Section reconsiders existing theories of market manipulation in light of HFT and proposes both a hybrid misrepresentation/manipulation theory, to which the fraudon-the-market presumption would apply, as well as the resurgence of open-market manipulation as a theory of liability.

1. Satisfying the market-efficiency predicate.

While the issue of market efficiency vis-à-vis HFT initially seems problematic, it is likely that after Halliburton II defendants will retreat from arguments about market efficiency and instead focus on questions regarding price impact and loss causation. ${ }^{151}$ Because evaluating (let alone proving) market efficiency is an arduous task, defendants seem more likely to avoid this point and instead devote their efforts to introducing price-impact evidence to rebut the fraud-on-the-market presumption. ${ }^{152}$ The Cammer court noted that the term "developed markets" generally refers to "large impersonal, actively traded markets." 153 These

150 See notes 8 and 10 , and accompanying text.

151 See Part I.B.3.

152 See Comolli and Starykh, Recent Trends at *1 (cited in note 82) (noting that defendants in the three post-Halliburton $I I$ securities class actions to date all introduced arguments about price impact).

153 Cammer, 711 F Supp at 1277, quoting Jeffrey E. Fleming, Securities FraudThird Circuit Adopts Fraud-on-the-Market Theory of Causation in 10b-5 Actions, 32 Vill L Rev 913, 936 n 85 (1987). 
characteristics intensify as markets with HFT become larger (as the volume of trading increases), more impersonal (as algorithms do more work), and more actively traded (as more trades occur) than markets without HFT. Recognizing these changes, defendants might devote fewer resources to challenging findings of market efficiency.

Further, it can be argued that HFT, so long as it occurs on national exchanges, does not affect market efficiency. Because "a large percentage of activity on NASDAQ"154 can be classified as HFT, there might still be a presumption that the market is efficient notwithstanding the introduction of HFT. As previously discussed, some courts have already recognized that large national markets like NASDAQ are entitled to a presumption of efficiency. ${ }^{165}$

Additional arguments can be made to support this shift in defense strategy based on the Supreme Court's language in earlier cases. Some scholars argue that Basic did not require a formal definition of "efficiency" and that the Court "did not find it necessary to set forth a rigorous test for market efficiency," because it pragmatically recognized the difficulty of assuming this task. ${ }^{156}$ In acknowledging that the Exchange Act is premised on "a philosophy of full disclosure,"157 the Court has previously noted that it "need only believe that market professionals generally consider most publicly announced material statements about companies" to find the efficiency predicate satisfied. ${ }^{158}$

A distinguished group of law professors and former SEC officials writing as amici in Halliburton II agreed with this viewpoint, arguing that the efficient-markets hypothesis "was never designed to prove causation or reliance in securities cases, or to be applied by judges and juries." 159 Indeed, these amici noted that forcing courts to make determinations of market efficiency has resulted in exactly the confusion that Justice Byron

154 Staff of the Division of Trading and Markets, Literature Review at * 13 (cited in note 114). Empirical studies have shown that HFT firms had trade-participation rates of 68.3 percent dollar volume, and that the HFT percentage of aggressive sides (the sides that traded immediately) and passive sides (the sides resting on an order when an ag. gressive order arrived) were $\mathbf{4 2 . 2}$ percent and 41.2 percent, respectively. See id.

155 See notes 59-60 and accompanying text. See also, for example, In re DVI, 639 F3d at 634 (noting that the listing of a security on a major exchange weighs in favor of a finding of market efficiency).

156 Black, 44 Loyola U Chi L J at 1501-04 (cited in note 28).

157 Basic, 485 US at 230 (quotation marks omitted).

158 Id at $246 \mathrm{n} 24$.

159 Law Professors' Brief at *6 (cited in note 50). 
White foretold in Basic: "traditional legal analysis [has been] replaced with economic theorization by the federal courts." 160 With HFT's entry into the market, determinations of market efficiency will become more difficult and more rooted in economic theory-lending credence to White's concerns. ${ }^{161}$ Some non-HFT defendants in pre-Halliburton II cases conceded market efficiency for the securities at issue; ${ }^{162}$ parties may similarly resort to stipulations of market efficiency in HFT cases to avoid the problem altogether.

Of course, some litigants may see market efficiency as the easier argument and choose to focus on this predicate rather than employ experts to provide event studies that show an absence of price impact. Due to the lack of consensus from economic commentators, this is another potentially viable strategy-but it may turn out to be undesirable in the future if and when highfrequency traders seek to bring suits as plaintiffs and need to prove market efficiency themselves. Because HFT adds volatility to the market and forces an overvaluation of short-term information that raises costs for traditional investors, courts may identify factors other than available information that can shape prices. Indeed, yet another possibility is that HFT defendants will prefer to settle actions to avoid disclosing their proprietary HFT strategies through discovery-public knowledge of which would erase any advantage that they had in the market. ${ }^{163}$ While efficiency will undoubtedly remain a contentious issue, it remains to be seen how prevalent these debates will be in litigation after Halliburton II.

160 Id at *7, citing Basic, 485 US at 252 (White dissenting).

161 For a discussion of the competing economic theories at play, see Part II.B.

162 See, for example, Amgen Inc v Connecticut Retirement Plans and Trust Funds, 133 S Ct 1184, 1190 (2013).

163 For an illustration of how valuable these algorithms are, see United States $v$ Aleynikov, 737 F Supp 2d 173, 175 (SDNY 2010). Sergey Aleynikov, a former programmer at Goldman Sachs, was convicted of stealing and transferring some of the source code for Goldman Sachs's HFT systems upon his departure from the firm. Goldman Sachs originally acquired these systems in 1999 for approximately $\$ 500$ million. Id. Aleynikov was given a sentence that initially included ninety-seven months' imprisonment followed by a three-year supervised release, as well as a $\$ 12,500$ fine; this sentence was later reversed. United States $v$ Aleynikov, 676 F3d 71, 73-75 (2d Cir 2012). A second conviction was filed in state court on similar grounds and recently overturned. See Decision and Order, People v Aleynikov, No 4447, *2 (NY Sup filed July 6, 2015). 


\section{Arguments from the City of Providence litigants.}

There are currently a handful of suits pending against national securities exchanges alleging violations of the federal securities laws based on the presence of HFT in those markets. ${ }^{164}$ Unfortunately, the initial briefing from City of Providence, the largest of these cases, did not elaborate on how the reliance requirement in Rule $10 \mathrm{~b}-5$ or the fraud-on-the-market presumption might apply to HFT cases. Rather than invoke a presumption of reliance, the plaintiffs instead argued that class members "relied on the integrity of the market" in trading on the public exchanges run by the defendants; essentially, the exchanges' statements regarding their integrity were the allegedly actionable misrepresentations under Rule 10b-5. ${ }^{165}$ Perhaps in an attempt to dissuade the court from invoking fraud on the market sua sponte, the defendants noted that the presumption was inapplicable because the plaintiffs did not plead the existence of an efficient market for a specific security as Basic requires. ${ }^{166}$

In support of their motion to dismiss, the defendants presented several additional arguments to rebut allegations of misrepresentations, which provide insight into how future plaintiffs might tailor their claims to allow application of the fraud-on-themarket presumption. First, the defendants argued that the institutional investors lacked standing to assert a Rule 10b-5 claim because the complaint "[did] not identify any specific purchase or sale of any specific security." 167 Because the Second Circuit has previously rejected the notion that anyone who merely makes use of the markets has standing to bring a Rule 10b-5 claim, ${ }^{168}$ the defendants argued that specific transactions of specific securities must be noted in the complaint. ${ }^{169}$ Although the court's decision is still pending at the time of this writing, future plaintiffs can avoid this attack by pointing to specific trades as a basis for their alleged losses. For example, showing the presence

164 See notes 132-42 and accompanying text.

165 Providence Amended Complaint at * 136 (cited in note 100).

166 Memorandum of Law in Support of Exchange Defendants' Motion to Dismiss the Consolidated Amended Complaint pursuant to Federal Rules of Civil Procedure 12(b)(1) and 12(b)(6), City of Providence v BATS Global Markets, Inc, Civil Action No 14-2811, *46-47 (SDNY filed Nov 3, 2014) ("Defendants' MTD Memo"), citing Basic, $485 \mathrm{US}$ at 247.

167 Defendants' MTD Memo at *37 (cited in note 166).

168 See Ontario Public Services Employees Union Pension Trust Fund v Nortel Networks Corp, 369 F3d 27, 32, 34 (2d Cir 2004).

169 Defendants' MTD Memo at *37 (cited in note 166). 
of high-frequency traders in the market for the particular security in which the plaintiffs traded would point to a specific transaction and would help plaintiffs demonstrate standing to bring their claims.

Second, the defendants argued that the complaint did not adequately identify fraudulent statements that were false and misleading to investors. ${ }^{170}$ In the defendants' view, the closest the plaintiffs came to identifying a specific statement as misleading was in their allegations that the exchanges sought to maintain "fair and orderly" markets and provide investors with equal access to markets and information. ${ }^{171}$ However, the Second Circuit has previously established that "general statements about reputation, integrity, and compliance with ethical norms are inactionable," as they are "too general to cause a reasonable investor to rely upon them." 172 Again, while the court's evaluation of these arguments is still forthcoming, future plaintiffs may be better served by looking to misrepresentations made by actual HFT firms themselves regarding the firms' trading behavior.

Separately, an interesting exception to the generally inactionable nature of statements regarding the integrity of the marketplace arises with alleged misrepresentations about a firm's dark pool. For example, in an action against the Barclays dark pool, the plaintiffs based their claims on Barclays's description of its dark pool as a "safe haven" for investors, insulated from aggressive and predatory HFT practices. ${ }^{173}$ The plaintiffs alleged that, contrary to this statement, Barclays actively courted HFT firms for the dark pool and provided them with material nonpublic information, giving them an unfair advantage over other traders. ${ }^{174}$ This suit was eventually consolidated with City of Providence. ${ }^{175}$

Third, the City of Providence defendants countered claims of Rule 10b-5 market manipulation by arguing that the plaintiffs failed to properly allege that the exchanges engaged in conduct with the specific purpose of affecting the market price of any

\footnotetext{
170 Id at *43-46 (cited in note 166 ).

171 Providence Amended Complaint at *37, 41 (cited in note 100).

172 City of Pontiac Policemen's and Firemen's Retirement System v UBS AG, 752 F3d 173, 183 (2d Cir 2014).

173 In re: Barclays Liquidity Cross and High Frequency Trading Litigation, 2014 WL 7180624, *1 (JPML) (consolidated on Dec 12, 2014).

174 Id.

175 Id at * $1-2$.
} 
security. ${ }^{176}$ The defendants made a similar argument regarding the plaintiffs' failure to adequately prove loss causation, as there was no identification of "what loss they incurred in trading on what security on which [e]xchange at what time." 177 Had the plaintiffs chosen to include HFT firms as defendants in addition to the exchanges, there would perhaps have been valuable market manipulation claims; however, the plaintiffs would still have needed to prove that the defendants acted for the express purpose of changing the market price of a particular stock. ${ }^{178}$ These shortcomings lead to a corresponding difficulty in proving reliance for a Rule $10 \mathrm{~b}-5$ claim, as it is not clear what misrepresentation or manipulative act the plaintiffs relied on. The plaintiffs did not assert any $\S 9$ claims of market manipulation, likely because they did not want to bear the burden of proving specific intent.

\section{Market manipulation reconsidered in light of HFT.}

Plaintiffs bringing suits against high-frequency traders and HFT firms may find greater success in combining the various theories of liability for market manipulation. HFT plaintiffs might be well equipped to bring a hybrid strategy combining elements of open-market manipulation with the fraud-on-themarket presumption of reliance. Such a strategy would enable plaintiffs to avoid the more stringent intent requirements of $\S 9$, while also avoiding potentially difficult reliance issues. Courts tend to interpret fraud on the market as a variation of a misrepresentation case rather than as a market manipulation case. ${ }^{179}$ However, there appears to be some gray area between these two doctrines that would allow the extension of the presumption to claims against high-frequency traders based on their allegedly manipulative behaviors.

176 Defendants' MTD Memo at *40-41 (cited in note 166 ).

177 Id at * 47 (emphasis in original).

178 See ATSI Communications, Inc $v$ Shaar Fund, Ltd, 493 F3d 87, 101 (2d Cir 2007). Various HFT firms were initially included as defendants in the original complaint but were removed in the Second Consolidated Amended Complaint. One possible reason for this removal might be that the plaintiffs found it difficult to identify the firms actually engaging in the HFT that caused the alleged injury; such practical difficulties will need to be addressed if this type of litigation is to succeed.

179 See, for example, Desai v Deutsche Bank Securities, Ltd, 573 F3d 931, 945 (9th Cir 2009) (O'Scannlain concurring) ("It is true that the fraud on the market theory is normally phrased in terms of misrepresentations or omissions."). See also Black, 52 Albany L Rev at 939 (cited in note 9). 
The fraud-on-the-market presumption is often unavailable to plaintiffs making market manipulation claims, ${ }^{180}$ likely because one of the requirements for bringing a Rule 10b-5 manipulation claim is "an assumption of an efficient market free of manipulation." 181 However, in certain situations some courts have held otherwise. For example, the pre-Basic case Chemetron Corp $v$ Business Funds, Inc ${ }^{182}$ held that when a $\S 10(\mathrm{~b})$ claim involves market manipulation conducted via fraudulent misstatements, the plaintiff must still establish reliance and can do so via a presumption of reliance. ${ }^{183}$ The plaintiffs in Chemetron alleged a "plan, scheme, or conspiracy to manipulate the price of [the defendant company's] stock through actual or apparent trading, thereby inducing transactions by others." ${ }^{184}$ A more recent district court decision, Scone Investments, LP v American Third Market Corp, ${ }^{185}$ also found the fraud-on-the-market presumption "especially applicable in the market manipulation context" when such schemes intentionally distort the price of a security. ${ }^{186}$ The manipulative behavior at issue in Scone Investments was also a series of trades designed to "inflate the price of the designated securities by creating the appearance of demand."187 Additionally, one scholar has argued that the fraud-on-the-market presumption should be extended to market manipulation claims, reasoning that such plaintiffs should not be required to demonstrate the existence of an efficient market to benefit from the presumption, and rather should have to show only loss causation. ${ }^{188}$

As such, misrepresentations about trading activities and misleading trades themselves could give rise to Rule 10b-5

180 See, for example, Desai, 573 F3d at 942 (finding that the district court did not abuse its discretion in declining to apply the fraud-on-the-market presumption in a market manipulation case).

181 ATSI Communications, 493 F3d at 101. See also text accompanying note 10.

182718 F2d 725 (5th Cir 1983).

183 Id at 728. See also Black, 52 Albany L Rev at 950-51 (cited in note 9). Note that Chemetron has no precedential force because the original panel action was vacated and remanded by the Supreme Court; on remand, the panel opinion was ordered for rehearing en banc and vacated. See Chemetron, 718 F2d at 730.

184 Chemetron Corp v Business Funds, Inc, 682 F2d 1149, 1155 (5th Cir 1982).

1851998 WL 205338 (SDNY).

186 Id at * 4 .

187 Id at * 1 .

188 See Korsmo, 52 Wm \& Mary L Rev at 1171-76 (cited in note 4). Because the efficient-market predicate of the fraud-on-the-market presumption would technically require the absence of manipulation, requiring proof of efficiency from plaintiffs seeking to bring such claims would make their cases impossible. See id at 1162-63. 
actions. Even HFT firms' statements about the impact that their behavior has on the market could lead to actionable misrepresentations. Indeed, courts and scholars have argued that a presumption of reliance should apply to misstatements about how specific trades are executed as well as to misstatements affecting the prices of specific securities. ${ }^{189}$ For example, one large HFT firm touts itself as "lower[ing] costs for both retail and institutional investors by supplying competitive bids and offers, without seeking to take on risky directional positions." $190 \mathrm{HFT}$ firms might face difficulties if such statements turn out to be false or misleading. Premising reliance on misstatements about a market for securities would shift plaintiffs away from the narrow pleading requirements of $\S 9$ manipulation and over to $\S 10(\mathrm{~b})$ misrepresentations, allowing access to the Basic presumption as well.

In addition, suits against HFT firms provide the ideal setting for resurgence of the open-market manipulation theory. Aggressive HFT strategies appear to convey exactly the false impression of supply and demand that open-market manipulation typically requires. ${ }^{191}$ The strategies of smoking and spoofing both involve high-frequency traders deliberately posting orders to the market that they have no intention of fulfilling, just to attract slower traders. High-frequency traders then either rapidly reverse their orders onto less-generous terms (smoking) or repeatedly post and cancel their orders (spoofing) to create a false appearance of market activity. ${ }^{192}$ Such behaviors appear to be precisely the form of manipulative trading anticipated by $\S \S 9$ and 10(b), as they have the "purpose of artificially depressing or inflating the price of the security" through facially legitimate transactions. ${ }^{193}$

These strategies also satisfy the Second Circuit's requirements for an open-market manipulation claim: profit or personal gain to the alleged manipulator, deceptive intent, market

189 See, for example, Stanislav Dolgopolov, A Two-Sided Loyalty?: Exploring the Boundaries of Fiduciary Duties of Market Makers, 12 UC Davis Bus L J 31, 61 (2011), quoting In re NYSE Specialists Securities Litigation, 405 F Supp 2d 281, 318-19 (SDNY 2005) ("Just as information about a specific security is reflected in the price of that security, so too is information about the manner in which transactions would be completed reflected in the price of securities generally.").

190 Company Overview (Virtu Financial, 2015), archived at http://perma.cc/2FVJ -RGFB.

191 See notes 12-19 and accompanying text.

192 See note 104 and accompanying text.

193 ATSI Communications, 493 F3d at 100-01. 
domination, and economic reasonableness of the alleged transaction. ${ }^{194}$ Note the marked absence of a reliance requirement. The market-domination factor may at first seem troublesome for HFT due to the extremely short length of time for which traders hold shares; however, because the Second Circuit makes this determination by looking to the total percentage of a security's trades that is carried out by any one actor rather than the trader's longer-lasting position, the behavior of HFT firms is likely to fall within this category. ${ }^{195}$ Recall that in the SEC's enforcement action against Athena Capital, for example, Athena's manipulative trading made up more than 70 percent of the total NASDAQ trading volume of the affected stocks in the seconds preceding the market close. ${ }^{196}$ Such a high percentage would undoubtedly satisfy the Second Circuit's threshold for market domination when viewed in the appropriate window of time. ${ }^{197}$

Another challenge is that market manipulation claims are typically moot when the conduct at issue has been "disclosed to the market." 198 However, because HFT strategies are proprietary and very closely guarded, they likely do not run afoul of this requirement. If plaintiffs are able to plead such claims with particularity, presumably by identifying the specific firms and trades that caused the alleged injury, they might find courts sympathetic to expanding Rule 10b-5 liability to open-market manipulation and might additionally find relief under $\S 9$. Importantly, for claims of either open-market manipulation under $\S 10(b)$ or market manipulation under $\S 9$, plaintiffs would not have to prove reliance. Plaintiffs would therefore have an alternative route to recovery, should the fraud-on-the-market presumption be inapplicable.

194 See United States v Mulheren, 938 F2d 364, 370-72 (2d Cir 1991). See also notes 12-19 and accompanying text.

195 See Mulheren, 938 F2d at 371.

196 See SEC Charges New York-Based High Frequency Trading Firm (cited in note 129). See also notes 129-31 and accompanying text.

197 In Mulheren, the Second Circuit compared and discussed different percentages of trading that would satisfy the domination requirement: 50 percent over a one-year period, 28.8 percent of daily exchange volume, and 83 percent in the final three hours of trading. All of these examples resulted in a finding of market domination and manipulation by the defendants. See Mulheren, 938 F2d at 371-72.

198 In re Merrill Lynch Auction Rate Securities Litigation, 704 F Supp 2d 378, 390 (SDNY 2010) ("The market is not misled when a transaction's terms are fully disclosed."). 


\section{B. High-Frequency Traders as Plaintiffs in Securities Class Actions}

With high-frequency traders occupying an ever-increasing share of the market, courts may eventually have to confront the question of these traders' legal recourse under the Exchange Act. As with any new technology, what at first seems unfair and deceptive may later become commonplace. For example, when electronic trading first entered the market, Cantor Fitzgerald, $L P v$ Cantor $^{199}$ arose as a challenge to these new technologies. In that case, a leading interdealer brokerage firm brought suit against a competitor based on the competitor's development of a new electronic trading system. ${ }^{200}$ The court acknowledged that "the electronic trading of securities [was] 'the wave of the future' and that the whole industry [was] moving in that direction" 201 and accordingly denied the plaintiffs' request for a preliminary injunction-allowing the technology to enter the market. ${ }^{202}$ Seventeen years removed from this case, pit trading is now "fast fading into history as the trading of stocks" becomes electronic. ${ }^{203}$

At the time of this writing, virtually no commentators have discussed whether high-frequency traders may have access to a private right of action. ${ }^{204}$ While these traders may not be the most "sympathetic plaintiffs," 205 they may suffer losses in the same way that traditional traders do. For example, because high-frequency traders often close out their positions at the end of the trading day, a misrepresentation that negatively affects the share price of a security may force traders to incur greater losses in selling their positions at the end of the day. ${ }^{206}$ The

199724 A2d 571 (Del Chanc 1998).

200 Id at 575.

201 Id at 579 n 21.

202 Id at 589.

203 See Jerry W. Markham and Daniel J. Harty, For Whom the Bell Tolls: The Demise of Exchange Trading Floors and the Growth of ECNs, $33 \mathrm{~J}$ Corp L 865, 866 (2008).

204 But see Stanislav Dolgopolov, Providing Liquidity in a High-Frequency World: Trading Obligations and Privileges of Market Makers and a Private Right of Action, 7 Brooklyn J Corp Fin \& Comm L 303, 351 (2013) (contemplating the possibility of highfrequency traders using a private right of action).

205 Id.

206 See 75 Fed Reg at 3606 (cited in note 89) (noting that high-frequency traders aim to end each "trading day in as close to a flat position as possible (that is, not carrying significant, unhedged positions overnight)"). 
treatment of suits seeking recovery for losses of this type is ripe for consideration because the unique characteristics of HFT pose many problems regarding standing, reliance, and class certification should investors continue to use the existing framework for recovery. This Section argues that, by virtue of comparison to short sellers, high-frequency traders have standing to bring suit under the securities laws. However, due to procedural complications in meeting class-certification requirements and proving the fraud-on-the-market predicates, it is unlikely that the Basic presumption would apply to a plaintiff class of high-frequency traders, and these suits are therefore unlikely to move forward. Consequently, the growth of HFT may be a boon for would-be defendants in securities-fraud class actions: due to typicality and predominance issues, the presence of highfrequency traders in a plaintiff class may bar class certification in certain situations.

1. High-frequency traders will have difficulty meeting the requirements of FRCP 23.

As a threshold matter, the class-certification requirements of FRCP 23 raise the question whether investors who purchased their shares via HFT can participate as class members in securitiesfraud class actions with conventional computerized traders as the lead plaintiffs. The typicality and adequacy prongs of FRCP $23(\mathrm{a})^{207}$ and the predominance requirement of FRCP 23(b)(3) ${ }^{208}$ present barriers for such plaintiffs.

The typicality and adequacy prongs require that "[e]ach plaintiff, in an individual suit, would be seeking to prove facts that would entitle the others to recover."209 This requirement presents problems for high-frequency traders serving as lead plaintiffs in a securities-fraud class action due to their unique reliance issues compared with those of conventional traders in the putative class. Indeed, courts have previously rejected individuals with characteristics similar to high-frequency traders as

207 FRCP 23(a)(3) ("One or more members of a class may sue or be sued as representative parties on behalf of all members only if . . the claims or defenses of the representative parties are typical of the claims or defenses of the class.").

208 FRCP 23(b)(3) ("A class action may be maintained if ... the court finds that the questions of law or fact common to class members predominate over any questions affecting only individual members.").

209 Kermit Roosevelt III, Defeating Class Certification in Securities Fraud Actions, 22 Rev Litig 405, 410 (2003). 
lead plaintiffs on reliance grounds. These courts have noted that a high frequency of trades can "raise a unique defense regarding lack of reliance on material misstatements and omissions," and that a record of a high frequency and high volume of trades can "raise serious concerns" about a lead plaintiff's typicality and "his susceptibility to the defense that he was trading in response to information other than the alleged misstatements and omissions" of the defendant. ${ }^{211}$ Class certification with an atypical lead plaintiff is denied when "there is a danger that absent class members will suffer if their representative is preoccupied with defenses unique to it." ${ }^{212}$ Consequently, a court may reject a high-frequency trader as lead plaintiff for a class of traditional investors due to the unique defenses that might be relevant to high-frequency traders.

Despite difficulties in acting as lead plaintiffs, highfrequency traders may still be able to participate in a class. There is evidence that high-frequency traders typically compete against other high-frequency traders rather than against longterm investors; 213 this finding may imply that a class could be certified if it were a class of only high-frequency traders, rather than a mixed class of investors. Courts have recognized that conflicts of interest between different groups of plaintiffs do not impact the fitness of the plaintiffs generally and will often permit the construction of subclasses to resolve such conflicts. ${ }^{214}$ This practice is common in traditional securities-fraud class action litigation, wherein purchasers of different types of stock are often separated into distinct classes. ${ }^{215}$ So long as each subclass is "homogeneous, in the sense that every member of the subclass wants the same relief, and each subclass otherwise satisfies the

210 Bang v Acura Pharmaceuticals, Inc, 2011 WL 91099, *4 (ND Ill).

211 Applestein v Medivation, Inc, 2010 WL 3749406, *3 (ND Cal). Note that Bang and Applestein do not use the term "high frequency" in the technical sense of HFT, but rather refer to a high volume of computerized trades with little time between each trade.

212 Hanon v Dataproducts Corp, 976 F2d 497, 508 (9th Cir 1992), quoting Gary Plastic Packaging Corp v Merrill Lynch, Pierce, Fenner \& Smith, Inc, 903 F2d 176, 180 (2d Cir 1990). See also In re Cavanaugh, 306 F3d 726, 729-30, 741 (9th Cir 2002) (Wallace concurring) (noting that a party may be rejected as lead plaintiff if it is "subject to unique defenses that render such plaintiff incapable of adequately representing the class").

213 See, for example, Brown, Comment, 11 Appalachian J L at 220 (cited in note 85).

214 See, for example, In re Cendant Corp Litigation, 264 F3d 201, 244 n 25 (3d Cir 2001).

215 See, for example, Billitteri v Securities America, Inc, 2011 WL 3586217, *2, 16 (ND Tex) (approving a settlement agreement involving multiple classes of investors based on which entity they invested in and whether they had commenced arbitration). 
requirements for certifying a class, so that each could be the plaintiff class in a separate class action," there is no problem bringing the case as a single class action. Indeed, this can often be the "superior approach."216 Future plaintiffs may be able to use this strategy to create subclasses of high-frequency traders-or even subclasses of high-frequency traders who have used different trading strategies-to advance their cases past the class-certification stage.

2. High-frequency traders will have difficulty proving loss causation.

Even in class actions in which the plaintiff class is entirely made up of high-frequency traders, HFT plaintiffs will have difficulties proving loss causation due to the extremely short-term nature of HFT positions. Because it is rare for traders or firms to hold positions overnight, 217 it may be difficult to trace losses back to a particular misrepresentation or cause. Indeed, the fact that high-frequency traders hold their stock for only fractions of a second may make them ineligible for damages in the first place, as the loss experienced may not have had anything to do with a misrepresentation. ${ }^{218}$ It will be even harder to compose a certifiable class of traders to serve as plaintiffs if each trade occurred at a different time and took different information into account. Evaluating plaintiffs' claims of loss causation based on a specific misrepresentation or statement will require a careful examination of the timing of the trades vis-à-vis the statements; if a purchaser sold his shares quickly, before the truth emerged, the misrepresentation would not have resulted in a loss. ${ }^{219}$ But if the purchaser sold "after the truth [made] its way into the marketplace, an initially inflated purchase price might mean a later loss."220 Evaluating such a trader's claims will involve close scrutiny of his trading records and extensive event studies to show loss causation, rendering classwide analysis exceedingly difficult.

216 Johnson v Meriter Health Services Employee Retirement Plan, 702 F3d 364, 368 (7th Cir 2012).

217 See note 89 and accompanying text.

218 See Bang, 2011 WL 91099 at ${ }^{*} 6$ (noting that day traders and market makers with high trading volumes often trade "based on minor price fluctuations and [do] not necessarily rely on company statements" or misstatements).

219 See Dura Pharmaceuticals, Inc v Broudo, 544 US 336, 342 (2005).

220 Id (emphasis in original). 
Consequently, proving loss causation may seem futile for HFT plaintiffs: due to their large exposure and short holding times, it might not be feasible for high-frequency traders to prove losses. However, as Halliburton II emphasized that loss causation does not need to be proven or decided at the classcertification stage, these concerns may not impede litigation at the outset. Litigants have typically relied on expert witnesses and their event studies and linear regressions to "tease apart the various competing causes of observed market moves" to prove loss causation. ${ }^{221}$ With the introduction of HFT into the market, responses to misrepresentations and other material information often become "distinctly nonlinear,"222 leaving room in this space for new models and methods for conducting damages calculations. Over time, new damages models further developing and describing these effects may emerge in financial and economic literature to help plaintiffs show loss causation at the merits stage of their cases. Such models may be able to more accurately account for how HFT firms process market information and to better quantify the magnitude of these firms' advantages. Additionally, discovery after class certification may reveal more information about specific trades such as the length of time that shares were held and the exchanges on which the shares were purchased, which will similarly assist the plaintiffs in proving loss causation.

3. High-frequency traders may have standing, but reliance is still problematic.

Because of the extremely short nature of HFT positions, traders using these strategies could argue for analogous treatment of high-frequency traders and short sellers. This comparison would confer standing on high-frequency traders in spite of their rapid-fire trades, but it would also require proof of actual reliance-making a class action with high-frequency traders as the plaintiffs difficult to maintain. As such, while procedural issues may make class certification difficult, high-frequency traders may still have standing to sue as individuals.

Short sellers are investors who sell shares of stock they do not own, in anticipation that the price will decline, and then use

221 Zachary Ziliak, Pavitra Kumar, and Torben Voetmann, Key Complexities in High-Frequency Trading Litigation (Law360, June 27, 2014), archived at http://perma.cc/PJ7X-7T3F.

222 Id. 
the proceeds of the short sale to repurchase the shares at a later date. ${ }^{223}$ When short sellers bring suit against a corporation under Rule 10b-5, they typically argue that, due to the corporation's fraudulent misrepresentation, they were forced to buy additional shares to cover their short sale - shares that they would not otherwise have needed or wanted to buy. This was precisely the argument raised in Zlotnick $v$ TIE Communications. ${ }^{224}$ In that case, the plaintiff executed a short sale of one thousand shares of the defendant corporation's stock because he believed the stock was overvalued. Subsequent to that sale, the defendants allegedly made misrepresentations that artificially inflated the share price, including misrepresentations in press releases about earnings forecasts and sales agreements. The plaintiff was unaware of any deceptive practice and decided to make the purchases to cover his short position and cut his losses; he ended up suffering losses of approximately $\$ 35,000.225$ In analyzing the timing of the plaintiff's trades, the court found that "this investment, like most investments, involve[d] two transactions" and the fact that "the sale occur[red] 'before' the purchase [did] not affect [the court's] consideration of each separate transaction for the possible effects of fraud." 226 The covering purchase was an indicator that the trader had relied on the corporation's misrepresentation to his detriment.

High-frequency traders can make a similar argument if a misrepresentation hits the market, causing a drop in a stock or group of stocks. Traders might then be left owning shares of stocks that they do not want to own, selling these shares at the close of trading for losses that are small in each individual trade but perhaps large enough in the aggregate to warrant a class action. Because high-frequency traders hold positions for such short periods of time and often purposefully buy and sell to take advantage of spreads in the market, they display many characteristics indicative of short selling. High-frequency traders can

223 See Zlotnick v TIE Communications, 836 F2d 818, 820 (3d Cir 1988).

224836 F2d 818 (3d Cir 1988).

225 Id at 819 .

226 Id at 821. See also Ganesh, LLC v Computer Learning Centers, Inc, 183 FRD 487, 490 (ED Va 1998) ("[T]he fact that the sale occurs before the purchase does not obviate the fact that the holder of the short position is both a 'purchaser' and a 'seller' of the security. Both transactions are in need of protection from fraud, and they equally satisfy the requirements for standing.") (citations omitted). For an explanation of the standing requirements under the Exchange Act, see Blue Chip Stamps v Manor Drug Stores, 421 US 723, 750-55 (1975). 
be thought of as less extreme versions of short sellers: whereas short sellers sell before they even hold the underlying security, high-frequency traders get as close to this line as possible without crossing it. As such, if short sellers have standing to bring Rule 10b-5 claims, surely high-frequency traders have standing as well, given that they actually buy and sell the securities in the more intuitive trading order.

A major hurdle to proving standing in suits involving short selling is the fact that proving injury is also exceedingly difficult. Continuing the analogy, short sellers arguably "lack standing to avail themselves of the securities laws" both because they "effectively sold their stock before they purchased it" and because they have different purposes in trading than traditional investors. ${ }^{227}$ Because traders who know that a misrepresentation is inflating a security's price are more, not less, likely to execute their short sales, proof of transaction causation is virtually impossible. The inclusion of short sellers in a class can therefore "prevent plaintiffs from establishing materiality, reliance, or fact of injury with common proof, threatening predominance." 228 Rather than seeking to profit from a company's good fortune and strength, short sellers seek to gain from the company's decline.

However, in Zlotnick, the Third Circuit held (and no other circuit has yet questioned) that short sellers indeed have standing to pursue Rule 10b-5 claims because these traders both buy and sell securities. ${ }^{229}$ Short sellers can even be appointed lead plaintiffs for a class of shareholders. ${ }^{230}$ Indeed, even option traders, who arguably do not buy or sell securities, have standing to sue under Rule 10b-5 and the federal securities laws, ${ }^{231}$ so merely extending the ability to sue to high-frequency traders does not seem problematic in this regard.

Unfortunately for high-frequency traders, the analogous benefits end there. While the Third Circuit acknowledged that short sellers have standing to sue under Rule $10 \mathrm{~b}-5$, it declined to extend Basic's presumption of reliance to the traders

227 Ganesh, 183 FRD at 490.

228 Roosevelt, 22 Rev Litig at 414 (cited in note 209).

229 Zlotnick, 836 F2d at 821.

230 See, for example, Fields $v$ Biomatrix, Inc, 198 FRD 451, 461 (D NJ 2000).

231 See Fry $v$ UAL Corp, 84 F3d 936, 939 (7th Cir 1996); Deutschman v Beneficial Corp, 841 F2d 502, 508 (3d Cir 1988). Courts have also found that the fraud-on-themarket presumption protects option traders who trade on widely utilized markets. See, for example, Tolan v Computervision Corp, 696 F Supp 771, 773-74 (D Mass 1988). 
and instead required them to show actual reliance. ${ }^{232}$ Because the trader in Zlotnick "decided that the market price was not an accurate valuation of the stock at the time of his short sale," the court found it inappropriate to presume that it was "reasonable for him to rely on the market price at the time of his purchase." 233

The case for a presumption of reliance is even weaker for high-frequency traders. Traders using HFT likely do not have prior knowledge that a misrepresentation is affecting the stock price, and furthermore do not rely on price in the same way that short sellers do. Rather than rely on their individual notions of what the true value of the stock is, high-frequency traders instead rely on the existing demand for a particular stock. Without a preexisting market for a security, there is little room for a high-frequency trader to enter the market in the first place. Indeed, high-frequency traders are seemingly indifferent to the actual price of a security; so long as their entries fall within the current bid-ask spread and there is some price movement allowing them to move in and out of positions, they can reap large profits on the trade. Nevertheless, HFT firms and traders may argue that, because HFT algorithms account for the behaviors of other traders, misrepresentations will harm high-frequency traders in the same way that they harm slower traders. However, this argument is weakened by the fact that high-frequency traders are better able to predict price movements than conventional computerized traders 234 - so they will also be ahead of any changes in the market when corrective disclosures are made and the truth is revealed. ${ }^{235}$ In this sense, high-frequency traders rely even less on market prices than short sellers-who at least initially base their individual valuations on the market price - and should be similarly unable to invoke a presumption of reliance.

232 Zlotnick, 836 F2d at 822-23.

233 Id at 823.

234 See note 110 and accompanying text.

235 See, for example, Lewis, Flash Boys at 268-69 (cited in note 87) (noting that high-frequency traders who can detect changes in the market can warn their computers in New Jersey of price movements in Chicago and then withdraw bids for individual stocks before the rest of the market realizes that the price has fallen). 


\section{CONCLUSION}

In coming years, HFT will change the existing landscape of securities class actions. The implications of HFT on determinations of market efficiency are uncertain, and the new technologies and strategies that continue to be introduced into the market will present novel challenges-procedural and otherwise - for courts to address as more cases are litigated.

While Halliburton $I I$ altered the mechanics of securities class actions and the fraud-on-the-market presumption, it did so in a way that encourages more discovery and research early in a case and as yet has an unknown impact on litigation. Earlier consideration of price-impact evidence might encourage a shift away from arguments about efficiency-a contentious point among empirical economists and jurists alike-or might result in more battles of the experts as new, untested damages models emerge from the financial literature. Shifting the proof of loss causation to after the class-certification stage will give litigants time to develop the event studies and additional data regarding HFT to make such showings.

The current state of litigation involving HFT, in the form of suits like City of Providence, reflects the prevailing view that high-frequency traders are villains. As such, claims of market manipulation and fraudulent misrepresentation have been the most popular and, consequently, the fraud-on-the-market presumption will likely continue to be an effective tool for these plaintiffs. A hybrid misrepresentation/manipulation claim may also be useful against HFT defendants, and indeed, some courts have recognized an opening for a fraud-on-the-market theory when misrepresentations are made about the market in which a security trades. Additionally, because high-frequency traders seek to profit off of slower traders and to create a false impression of market activity through facially legitimate trades, plaintiffs bringing these claims should look to revive the Rule 10b-5 theory of open-market manipulation for recovery. Such a strategy would remove the reliance requirement, which would be advantageous to plaintiffs if the fraud-on-the-market presumption proves inapplicable.

Like many other new technologies, however, HFT may reach a point of such widespread adoption that it will be used not only by banks' in-house proprietary traders but also by individual investors. At that point, judges ruling on certification motions for putative classes of HFT investors will need to consider 
some of the procedural issues addressed in this Comment. The comparison of high-frequency traders to short sellers suggests that HFT plaintiffs should have standing to sue and that they may also serve as lead plaintiffs in these actions. Similarly, based on existing class actions involving variegated investors within the same suit, high-frequency traders could structure and subdivide their plaintiff classes to avoid issues of typicality and predominance that might otherwise prevent access to classwide relief. However, issues of reliance will likely prove insurmountable for HFT plaintiffs due to the traders' seemingly absent concern for the market price of the securities in which they trade.

In the coming years, HFT-related issues beyond those discussed in this Comment will undoubtedly surface and eventually reach courtrooms across the country. Regardless of whether high-frequency traders come to court as plaintiffs or defendants, the advent of HFT marks a changed circumstance that the securities-litigation bar will have to wrestle with in the near future. 


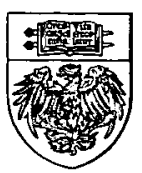

